\title{
A Church and a Castle \\ Centre and Periphery of the Empire in duke Ottavio Piccolomini's self-representation
}

\section{ALESSANDRA BECUCCI}

\section{Introduction}

On May 4th 1634 Ottavio Piccolomini Pieri d'Aragona (1599-1656), colonel general of the Habsburg army, received confirmation from one of his agents in Vienna that the estate of Náchod, in Eastern Bohemia, had been assigned to him by the Emperor Ferdinand II. ${ }^{1}$ The assignation proceeded from Piccolomini's involvement in February 1634 in the elimination of the alleged traitor generalissimo Albrecht von Wallenstein, duke of Friedland (1583-1634). The assassination of the Bohemian general, one of the notable episodes in Thirty Years War, had been ordered by the Emperor and carried out by the generals under Wallenstein's command, Matthias Gallas (1584-1647), Johann Aldringen (1588-1634), Walter Leslie (1607-1667) and, remotely, Ottavio Piccolomini. All the generals involved in the event had been rewarded for their service and loyalty to the Emperor with a sum of money and the attribution of one of the estates formerly belonging either to Wallenstein, to his brother-in-law Adam Erdmann Trčka (1599-1634), or to his associate Christian Ilow (1585-1634), both killed together with him in Cheb. The delay in the attribution of the monetary reward, the expenses for the ceremony of investiture, the poor status of Náchod, amongst other reasons, prompted Piccolomini's several attempts to sell the estate already by the end of the same year. At the same time, though, Ottavio Piccolomini started diverting his funds, including the pending credits that he had at the imperial court and that had not yet been fulfilled to him, for the foundation of the church of the Servite order in Vienna. Only towards the end of his military activity, just married and determined to finally establish a Piccolomini lineage in the Habsburg territories, Piccolomini reconsidered an investment in Náchod, never eventually sold, to make of it his and his spouse's main residence. His involvement with the Servites remained constant throughout his life, more than with any other religious order he sponsored, and it enabled him to promote his patronage next to the one of the imperial court. The settlement of the Servites in Vienna took longer than initially hoped for and the church and convent - today the Servitenkirche in the Rossau quarter in Vienna - was not yet completed at the moment of Piccolomini's death.

1 Giulio Diodati from Vienna to Ottavio Piccolomini, 4 May 1634, 17301, Státní oblastní archiv Zámrsk [State Regional Archives Zámrsk] (hereafter SOAZ), Rodinný archiv Piccolominiové [Family Archive Piccolomini] (hereafter RAP). 
In this contribution, I discuss the role played by both the castle of Náchod and the church of the Servite order in Vienna in conveying a symbolic capital that was instrumental to Piccolomini's fashioning as a nobleman and a courtier at the imperial court, where despite the credit acknowledged to him for his political, military and diplomatic virtue, he was always perceived as a foreigner. ${ }^{2}$ I analyze the different effectiveness of these buildings as tools used by Piccolomini within distinguished urban contexts, at distinct stages of his career, to embody his identity as well as to represent his stance within the highly-competitive court society.

\section{Architecture as Self-representation in absentia}

In the Seventeenth century, self-representation through architecture had long been assimilated by Italian nobility. The expression of social identity, and the processes related to it, had been developed centuries earlier in the awareness that "the family palace and the family portraits (...) were forms of conspicuous consumption and means of impression management which no one who had or aspired to high status could do without. ${ }^{\text {"3 }}$ In fact, the very idea of being represented - and therefore of being seen and being present to the knowledge of any social audience even in absentia - had been developed at its best in Piccolomini's motherland, Tuscany, and, in this respect, he could certainly benefit from his family heritage and background. ${ }^{4}$ As the scion of the highest Sienese nobility, Piccolomini had had the chance to grow in Florence, within the context where the very expression of magnificence through

2 I use the concept of "fashioning“ as defined by Stephen Greenblatt, The Re-naissance Self-fashioning: From More to Shakespeare, Chicago 1980, to define the process of constructing one's own identity and public persona according to a set of socially acceptable standards.

3 Peter Burke, The Italian Renaissance. Culture and Society in Italy, Princeton 1986, p. 9. For the imperial area of interest, Friedrich Polleross, Adelige Repräsentation in Architektur und bildender Kunst vom 16. bis zum 18. Jahrhundert in Österreich. Literatur und Forschungsüberblick, Opera historica 2, 1992, p. 49-59; Hellmut Lonenz, Zur repräsentativen Raumfolge und Ausstattung der barocken Stadtpaläste Wiens, Kunsthistorisches Jahrbuch Graz 25, 1993, p. 291-304; IDEM, The Imperial Hofburg. The Theory and Practice of Architectural Representation in Baroque Vienna, in: Charles W. Ingrao (ed.), State and Society in Early Modern Austria, Indiana 1994, p. 93-109; IDEM, „....im alten Style glücklich wiederhergestellt... ". Zur repräsentativen Rolle der Tradition in der Barockarchitektur Mitteleuropas, Österreichische Zeitschrift für Kunst und Denkmalpflege 51, 1997, p. 475-483; Petr FidLER, „Bauen ist eine höhere Lust als Kriegführen“. Albrecht Wenzel Eusebius von Waldstein als Bauherr und Mäzen. Zur Baustrategie eines Fürsten, Opera historica 7, 1999, p. 275-309.

4 On Ottavio Piccolomini's biography, Arnold von Weıнe-Eıмке, Octavio Piccolomini als Herzog von Amalfi, Ritter des goldenen Vließes, deutscher Reichsfürst und Gemahl der Prinzessin Maria Benigna von Sachsen-Lauenburg, Quellen-Studie aus dem Schloß-Archive zu Nachod, Pilsen 1871; Enea Piccolomini, Sopra le ricerche e i giudizi del barone Arnoldo di Weyhe-Eimke intorno alla personalità storica del Max Piccolomini nel Wallenstein di Schiller, Archivio Storico Italiano 14, 1871, p. 213-249; Heinrich M. Richter, Die Piccolomini, Berlin 1874; Otto Elster, Octavio Piccolominis Sohn, Österreichische Rundschau 21, 1909, p. 49-58; Otto Elster, Piccolomini-Studien, Leipzig 
architecture had been taking shape since 1430s in the patronage of the Medici family. ${ }^{5}$ The uncommonly rich cultural background on which Ottavio Piccolomini could count was then accumulated in his childhood as a page at the Medici grand ducal court in the Pitti Palace, where his father, appointed chamberlain of the Grand Duke and educator of the prince heir, and his older brother Enea, a court page, were amongst Galileo Galilei's intimate friends. ${ }^{6}$ Even more relevant as for the efficacy of self-representation through architecture was the patronage of the most notable amongst Piccolomini's ancestors, the humanist Enea Silvio Piccolomini (1405-1464), from 1458 pope Pius II, known for his love for the arts and his political and diplomatic skills. Pius II, as a court poet of the emperor Frederick III (1415-
1493), as the first author since Tacitus' time to use the term "Germany“ (1457), as the author of a History of Bohemia (1458), was the natural reference for Ottavio Piccolomini, that had moved to the Habsburg territories at sixteen to spend his life in the service of the Empire. ${ }^{7}$ The Piccolomini pope had found the highest celebration of himself and his lineage through the urban re-planning of his native village, Corsignano, into the new foundation of the city of Pienza, regarded as the first realization of the humanist idea of urban design, modeled on the concept of the città ideale. ${ }^{8}$ Still nowadays several other Piccolomini palaces are defining the urban structure of Siena as landmarks in its historical center. There the magnificence of the family is not only expressed within the compass of the civic urban space through

1911, p. 44-59; Heinrich Bücheler, Von Pappenheim zu Piccolomini. Sechs Gestalten aus Wallensteins Lager. Biographische Skizzen, Sigmaringen 1994; Jürgen Woltz, Der kaiserliche Feldmarschall Ottavio Piccolomini - ein Lebensbild aus der Zeit des Dreißigjährigen Krieges, in: Josef J. Schmid (ed), Arte \& Marte. In memoriam Hans Schmidt. Eine Gedächtnisschrift seines Schülerkreises 2, Herzberg 2000, p. 93-145.

5 Anthony David Fraser Jenkins, Cosimo de' Medici's Patronage of Architecture and the Theory of Magnificence, Journal of the Warburg and Courtauld Institutes 33, 1970, p. 162-170. For the most recent historiographical survey see Emanuela Ferretti, The Medici Palace, Cosimo the Elder and Michelozzo: a Historiographical Survey, in: Silvia Beltramo - Flavia Cantatore - Marco Folin (edd.), A Renaissance Architecture of Power. Princely Palaces in the Italian Quattrocento, Leiden-Boston 2016, p. 263-289.

6 On Piccolomini's patronage in a European context and with respect to his family's tradition, Alessandra Becucci, L'arte della politica e la politica dell'arte nello spazio europeo del Seicento. Ottavio Piccolomini: contatti, agenti e acquisizioni d'arte nella Guerra dei Trent'anni, Florence 2012 (PhD thesis).

7 On the relationship between Tuscany and Bohemia, Lucia Bonelli Conenna - Alena Pazderová, Siena v Praze. Déjiny, umèní, společnost, Praha 2000.

8 Luigi Firpo, La città ideale del Rinascimento, in: Gianni Carlo Sciolla (ed), La città ideale nel Rinascimento, Torino 1975; Hanno-Walter Kruft, Städte in Utopia. Die Idealstadt vom 15. bis zum 18. Jahrhundert zwischen Staatsutopie und Wirklichkeit, Monaco 1989. 


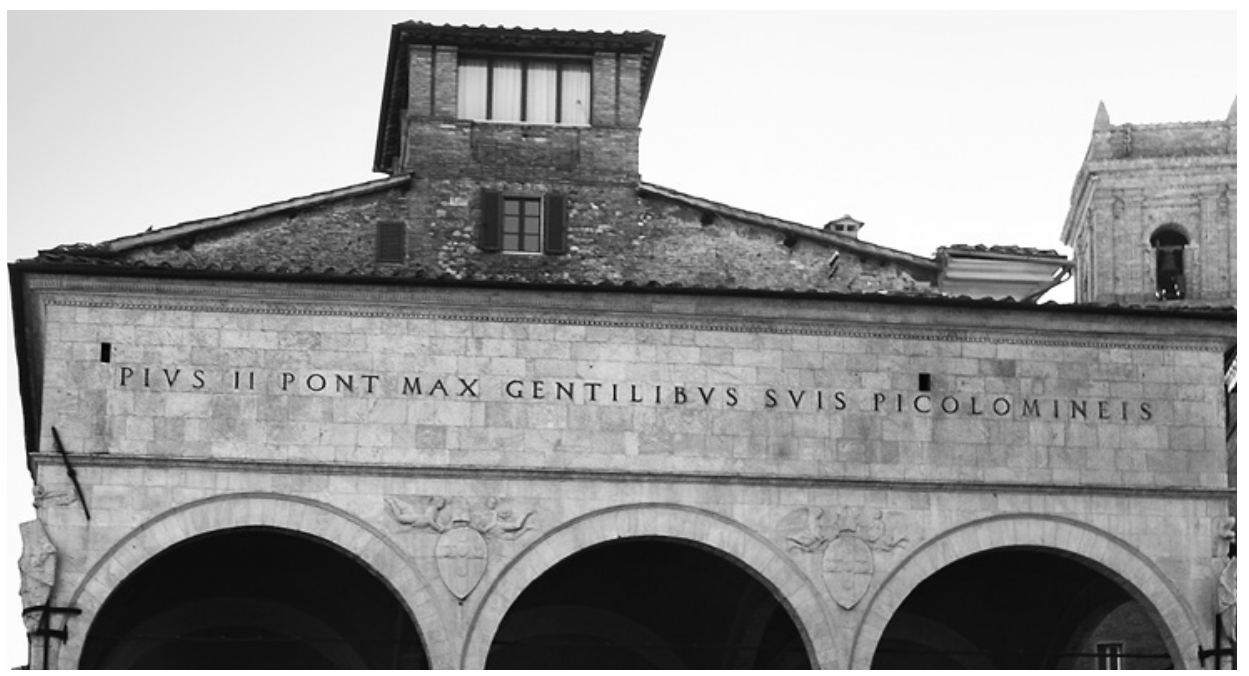

Figure 1 - Antonio Federighi, Loggia Piccolomini, Siena, 1462, commissioned by Pius II, detail (Photo by author)

the size and elegance of the buildings, but it is also embodied in the celebrative words on the Loggia that Pius II built gentilibus suis Piccolomineis (1462) next to the family palace, and represented to the detail no less than in the knockers of the palace's gates and in the decoration of the windows, featuring the crescent from the Piccolomini coat of arms. ${ }^{9}$ (Figure 1)

The most important religious building in Siena, the cathedral, also stands as one of the celebrative sites of the lineage, housing the most famous amongst the artistic commissions of the family, the impressive library that Pius II's nephew and successor, Pius III (1439-1503), humanist and patron, dedicated to the memory of his uncle to accommodate his books. The library was decorated by Pinturicchio with frescoes whose design is partly attributed to a young Raffaello (1483-1520). Next to the entrance of the library, the Piccolomini altar and burial monument was carried out by Andrea Bregno (1418-1506) with the participation of Michelangelo (1475-1564). ${ }^{10}$ The high level of this cultural patronage

9 On the importance of one's own ancestors for representation and promotion at the imperial court, Andreas PEČAR, Genealogie als Instrument fürstlicher Selbstdarstellung. Möglichkeiten genealogischer Repräsentation am Beispiel Herzog Ulrichs von Mecklenburg, Zeitenblicke 4, 2005, Nr. 2; IDEM, Das symbolische Kapital der Ahnen. Genealogische Inszenierungen Herzog Ulrichs von Mecklenburg in Güstrow, in: Kornelia von Berswordt-Wallrabe - Kristina Hegener - Regina Erbentraut (edd.), Ausstellungskatalog Schloß Güstrow: Prestige und Kunst 1556-1636, Schwerin 2006, p. 38-43.

10 On the patronage of the Piccolomini in Tuscany: Alessandro Angelini (ed.), Pio II e le arti. La riscoperta dell'antico da Federighi a Michelangelo, Siena 2005. 
coupled with the renown martial tradition of the family. As responsible for the arsenal of the Gran Ducal army and Constable of the military order of Saint Stephen, the fame of Ottavio's father, Silvio Piccolomini (1543-1612), had grown enough to be celebrated by Michel de Montaigne in the Journal of his travel to Italy (1580-1581). ${ }^{11}$ In his father footsteps, and following the destiny of a third-born nobleman, Ottavio received a military education and his career started out in the service of the Spanish crown in the Milanese region. He later followed his brother as captain of chivalry in the regiment that the Grand Duke of Tuscany had sent in assistance to his uncle the Emperor facing the Bohemian insurrection, he participated to the Battle of the White Mountain (1620) and later to the Battle of
Lützen (1632). ${ }^{12}$ The attribution of the estate of Náchod and of the 215,613 guilders occurred in May 1634 at the turning point in Piccolomini's career. (Figure 2)

After Wallenstein's assassination, in fact, he was able to climb the ranks of the military hierarchy. Yet, regardless for these honors, Piccolomini felt that his life and reputation at the court were constantly at stake. Notwithstanding the court's formal acknowledgement of the necessity of the action taken, after Wallenstein's death all the generals involved in the event had difficulties in fitting into the reorganization of the power dynamics at the court. ${ }^{13}$ The foreign nationalities of most of them - Italian, of Italian descent, Scottish and Irish - contributed to reinforce the prejudice against them, the German party

11 Michel de Montaigne, Journal du voyage de Michel de Montaigne en Italie, par la Suisse et l'Allemagne, en 1580 et 1581, avec de note par A. G. Meusnier de Querlon, Roma-Paris 1774, p. 116-117.

12 For a contextualization of Piccolomini's background in the shaping of cultural and political identity Alessandra Becucci, Ottavio Piccolomini (1599-1656): a case of patronage form a transnational perspective, The International History Review 33, 2011, p. 585-605.

13 On imperial court dynamics and aristocratic networks, Norbert Elias, Die höfische Gesellschaft. Untersuchungen zur Soziologie des Königtums und der höfischen Aristokratie mit einer Einleitung: Soziologie und Geschichtswissenschaft, Neuwied-Berlin 1969; Arthur G. Dickens, The Courts of Europe. Politics, Patronage and Royalty, 1400-1800, London 1977; Yves Durand, Hommage à Roland Mousnier. Clientèles et fidélités en Europe à l'epoque moderne, Paris 1981; Ronald G. Asch - Adolf M. Birke (edd.), Princes, Patronage, and the nobility. The Court at the Beginning of the Modern Age, c. 1450-1650, Oxford 1991; Jeroen Duindam, Miths of Power. Norbert Elias and the Early Modern European Court, Amsterdam 1994; Jörg J. Berns - Thomas Rahn (edd.), Zeremoniell als höfische Ästhetik in Spätmittelalter und Früher Neuzeit, Tübingen 1995; John Adamson (ed.), The Princely Courts of Europe, 1500-1750, London 1999; Thomas Winkelbauer, Fürst und Fürstendiener: Gundaker von Liechtenstein, ein österreichischer Aristokrat, Wien 1999; Rudolf SchlöGL - Mark Hengerer, Politische und soziale Integration am Wiener Hof. Adelige Bestattung als Teil der höfischen Symbol- und Kommunikationsordnung, Mitteilungen der Residenzenkommission der Akademie der Wissenschaften zu Göttingen 10, 2000, p. 15-40; Mark Hengerer, Hofzeremoniell, Organisation und Grundmuster sozialer Differenzierung am Wiener Hof im 17. Jahrhundert, in: Klaus Malettke - Chantal Grell (edd.), Hofgesellschaft und Höflinge an europäischen Fürstenhöfen in der Frühen Neuzeit (15.-18. Jh.), Münster 2001, p. 337-368; Ronald G. Asch, Nobilities in Transition, 1550-1700. Courtiers and Rebels in Britain and Europe, London 2003; Jeroen Duindam, Vienna e Versailles: the courts of Eu- 


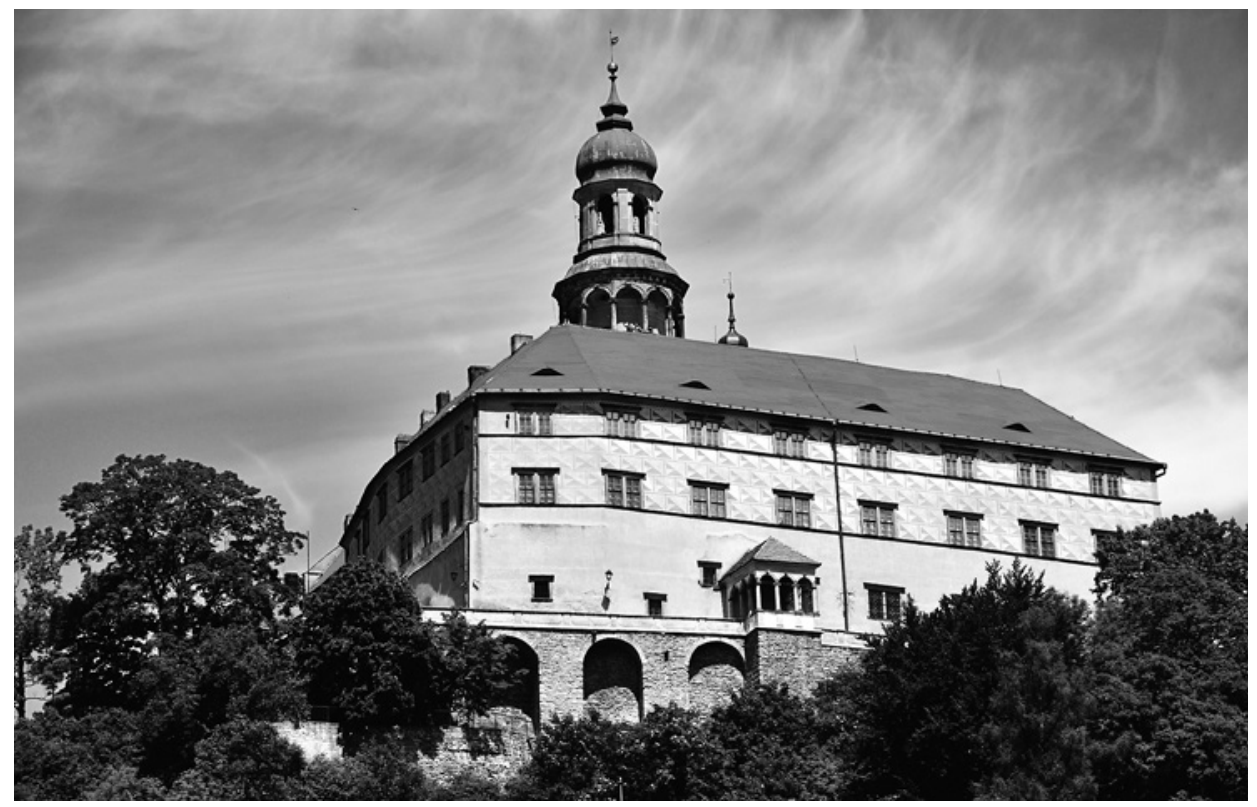

Figure 2-Náchod castle, Eastern Bohemia (Public domaine)

looking at them as traitors of their own commander. In this perspective, Piccolomini's betrayal was felt as particularly despicable, since his role of head of the generalissimo's bodyguard was believed to have allowed him to play two-faced. ${ }^{14}$

rope's major dynastic rivals, 1550-1780, Cambridge 2003; Martin Gosman - Alasdair MACDonald - Arjo Varderjagt (edd.), Princes and princely culture 1450-1650, Leiden-Boston 2003; Michael KaISer - Andreas PečAr, Der zweite Mann im Staat. Oberste Amtsträger und Favoriten im Umkreis der Reichsfürsten in der Frühen Neuzeit, Berlin 2003; Petr MAŤA, Svèt české aristokracie (1500-1700), Praha 2004; Jeroen Duindam, Vienna and Versailles. Materials for further comparison and some conclusions, (www.zeitenblicke.de; 13.12.2015); Thomas Win KELBAUER - István FAZE Kas - Martin Scheutz - Csaba Szabó, Frühneuzeitforschung in der Habsburgermonarchie. Adel und Wiener Hof - Konfessionalisierung - Siebenbürgen, Wien 2013 (= Publikationen der ungarischen Geschichtsforschung in Wien 7); Dries Raeymaekers - Sebastiaan Derks (edd.), The key to power? The culture of access in princely courts, 1400-1750, Leiden-Boston 2016.

14 This is apparent in the correspondence of Florentine ambassadors and agents in Vienna, reporting that Piccolomini believed that his life was in danger and, not to risk, he would send his captains to bring his messages at the court. Niccolò Sacchetti to the Medici court in Florence, 11 March 1634, 4587, Archivio di Stato di Firenze [State Archive in Florence], (hereafter ASF), Mediceo del Principato [The Medici Gran Ducal Archival Collection] (hereafter MDP); Sacchetti from Vienna to the Medici court in Florence, 1 April 1634, 4587, ibidem: (...) il grand'odio che si è tirato addosso dei parenti et partiali di Fridland e di quasi tutta questa nazione, che aborrisce il tradimento, sente però mal volentieri che si avanzino forestieri e chiede a Sua Maestà rigori grandi (...). 
Therefore, in the tense aftermath of Wallenstein's elimination, it was not advisable to be absent from the court for reasons other than the military service and leave room for repercussions. ${ }^{15}$ The need for an appropriate representation in Vienna was then particularly felt by Piccolomini, that had to rely on a network of agents composed by his nephews and subordinates and by his few peer friends at the court. ${ }^{16}$

After Wallenstein's death Rudolph Colloredo (1585-1657) received the castle of Opočno, Matthias Gallas had Friedland and Reichemberg, Johann Aldringen was assigned Teplice and Piccolomini was given the eastern estate of Náchod, former possession of Adam Trčka. Piccolomini's effective ownership of the estate was delayed, because of the time taken by the imperial court for the detailed description of all the assets owned by the executed traitors. Sources report of Piccolomini's intention to sell the castle soon after the ceremony for the investiture. In June 1634, posted at the imperial camp near Regensburg, Piccolomini gave mandate to his agent and confessor Paolo Orsini to represent him in the formal ceremony of the expensive taking of possession. Once ratified, the ownership would have facilitated the sale, for which offers had already been presented. ${ }^{17}$

Several factors contributed to Piccolomini's decision not to keep the castle. Notwithstanding the chance of reaping revenues from the estate, Piccolomini was prompted to get rid of it because of its constant state of ruin. Out of all the newly attributed estates, Náchod was in fact weakened by its most vulnerable location, exposed to enemies' attacks and therefore also frequently assigned with the quartering of imperial troops, either going to or returning from the

15 For archival sources on Piccolomini’s military and political involvement, Josef Kočí - Josef PoLišenský - Gabriela Čechová - Miroslav Toegel - Josef Kollmann - Vladimír Budil (edd.), Documenta Bohemica Bellum Tricennale illustrantia I-VII, Praha 1971-1981. On Wallenstein's vicissitude, Friedrich Parnemann, Der Briefwechsel der Generale Gallas, Aldringen und Piccolomini im Januar und Februar 1634. Ein Beitrag zum Untergange Wallensteins, Berlin 1911 (= Historische Studien 92), p. 612; Hubert Jedin, Die Relation Octavio Piccolominis über Wallensteins Schuld und Ende, Zeitschrift des Vereins für Geschichte Schlesiens 65, 1931, p. 328-357; Golo Mann, Wallenstein. Sein Leben erzählt von Golo Mann, Frankfurt am Main 1971; Pavel BALcárex, Chebská exekuce ve svétle korespondence s ř́mskou kurí, in: Alena Pazderová (ed.), Pocta Josefu Kollmannovi, Praha 2002, p. 6-45.

16 On self-representation at the imperial court and on agency in the early modern time, Marika Kebluser, Profiling the Early Modern Agent, in: Hans Cools - Marika Keblusek - Badeloch Noldus (edd.), Your Humble Servant. Agents in Early Modern Europe, Hilversum 2006; Marika Keblusek - Badeloch Noldus, Double agents. Cultural and political brokerage in Early Modern Europe, Leiden 2011. On Piccolomini's network of agents: Alessandra BEcuccI, A merchant, a secretary and a captain: cultural go-betweens in early modern Europe, in: Veronika Čapska - Robert Antonín - Martin Čapský (edd.), Processes of Cultural Exchange in Central Europe, 1200-1800, Opava 2014, p. 151-177.

17 Paolo Orsini to Piccolomini, 2 June 1634, 7, SOAZ, RAP; Piccolomini from the imperial camp near Regensburg to Orsini, 11 June 1634, 15, ibidem; Orsini from Prague to Piccolomini, 23 June 1634,8 , ibidem. The ceremony would entail the payment for the accommodation of eight imperial representatives and their families for a total of 72 mouths and 66 horses in the several stops along the way between Prague and Náchod and return. 
front. In 1635 only, the damages amounted to 159000 florins, for which Piccolomini's agents asked the emperor a waiver from the contribution, as applied to other estates, while movements of troops over the city and in the surrounding area are documented until 1650s. Furthermore, when selling, Piccolomini would eliminate a source of continuous expenses and administrative problems. Troubles in the remote management of Náchod through Piccolomini's agents were driven by the weakness and unwillingness of some of them, and particularly of his nephew, Francesco Piccolomini (1611-1658), that would use the revenues from the estate to repay his gambling debts, would spread the rumor that the estate had been donated to him by his uncle and would constantly try to swindle its administrators. ${ }^{18}$ The peripheral location implied a high economic investment and the need for a continued supervision that in the fourth decade, because of his military activity, Piccolomini could not provide. Besides the problematic remote managing mirrored in the correspondence, in fact, he had to face the constant need for liquidity to support his regiments throughout the end of 1640s. ${ }^{19}$ For this reason, at the same time with the taking of possession, Piccolomini requested from his agents an esteem of the estate, convinced that the Emperor would have reimbursed to him the difference between its value and the amount that he had had to pay for it. ${ }^{20}$

By December Piccolomini's network had already been activated for the sale and potential buyers had already made offers. The Barnabite friar Florio Cremona (1592-1649) had found someone willing to pay 50000 florins - payable in Italy, upon request, to spare Piccolomini the expenses of the change - and to give the equivalent of another 15000 florins in modern jewelry. ${ }^{21}$ The name of the buyer is not made explicit, though given the quality of the mediator Cremona - a member of the entourage of the archbishop of Prague, cardinal Ernst Adalbert von Harrach (1598-1667) - it may be inferred to have been a prominent personality. ${ }^{22}$ Cremona invited Piccolomini to consider that not

18 Orsini to Francesco Piccolomini, 9 October 1635, 172, SOAZ, RAP; Orsini to Piccolomini, 12 October 1635,173 , ibidem.

19 On the dynamics of the funding for the troops Fritz ReDLICH, Military Entrepreneurship and the credit system in the 16th and 17th centuries, Kyklos 10, 1957, p. 186-193; IDEM, The German Military Enterpriser and his work force. A Study in European Economic and Social History I-II, Wiesbaden 1964-1965.

20 Piccolomini from the imperial camp near Regensburg to Orsini, 11 June 1634, 15, ibidem. Piccolomini trusted he would have obtained 300000 florins, plus the 150000 of the cost of the estate.

21 Don Florio Cremona from Prague to Piccolomini, 31 December 1634, 11, ibidem: ,gioie alla moderna. “

22 On the relation between Cremona and Harrach Alessandro Catalano, Un episodio che non ha cambiato il corso della storia. L'assedio di Praga del 1648 in due testimonianze inedite, eSamizdat 2/1, 2004, p. 151-173, here p. 152, 153. On cardinal Harrach, Alessandro Catalano, La Boemia e la riconquista delle coscienze: Ernst Adalbert von Harrach e la Controriforma in Europa centrale (1620-1667), Roma 2005; Katrin Keller - Alessandro Catalano, Die Diarien und Tagzettel des Kardinals Ernst Adalbert von Harrach (1598-1667), Köln-Weimar-Wien 2010. 
only the castle was all ruined, but that in refurbishing it, even with the Peace of Solomon, it would take years and many ones, because of the universal destruction occurred. The formal taking of possession had opened the chance for more offers from potential buyers. Indeed, right after the investiture the castle had been fortified, equipped and given in custody to a garrison.

A mansion of his own property, differently from the temporary accommodations of the constantly reattributed court quarters in Vienna and from the rented houses that Piccolomini was always at difficulties to pay for, would have granted him the chance to establish his lineage in
Bohemia, as his older brother and advisor Ascanio Piccolomini (1590-1671), archbishop of Siena, would urge him to do. ${ }^{23}$

And yet, while temporarily taking advantage of the poor revenues of the estate, Piccolomini was determined to sell. Notwithstanding his military successes, the process of integration within the imperial court was not easy. ${ }^{24}$ It requested a constant presence and, in absentia, an adequate supplementary representation. The position of Náchod was peripheral not so much as to its being at the border of the territories controlled by the imperial troops, as it was, more importantly, far from Vienna. ${ }^{25}$ Piccolomini's presence in Vienna was, instead, necessary and

23 On nobility in Bohemia, Thomas Winkelbauer, Krise der Aristokratie? Zum Strukturwandel des Adels in den böhmischen und niederösterreichischen Ländern im 16. Und 17. Jahrhundert, Mitteilungen des Instituts für österreichische Geschichtsforschung 100,1992, p. 328-353; Václav BŮŽEK - Petr MAŤA, Wandlungen des Adels in Böbmen und Mähren im Zeitalter des „Absolutismus“(1620-1740), in: Ronald G. Ash (ed.), Der europäische Adel im Ancien Régime. Von der Krise der ständischen Monarchien bis zur Revolution (ca. 1600-1789), Köln-Weimar-Wien 2001, p. 287-321; Václav BŮžEK - Josef HrdLIČKA - Pavel KRÁL Zdeněk VYBíral, Věk urozených. Šlechta v českých zemích na prahu novověku, Praha 2002; Václav BůžEK - Pavel KráL (edd.), Šlechta v habsburské monarchii a císařský dvưr (1526-1740), České Budějovice 2003 (= Opera historica 10); P. MaŤA, Svèt, Petr MaŤA - Thomas Winkelbauer, Die Habsburgermonarchie 1620 bis 1740. Leistungen und Grenzen des Absolutismusparadigmas, Stuttgart 2006; Josef HrdLčKa, Seigneurie, résidence et cour à l'époque moderne: Jinřichưv Hradec, du XVI eau XVIIIe siècles, Historie, économie et société 3, 2007, p. 47-58; Petr MAŤA, Wandlungen des böbmischen Adels im 17. Jabrhundert und der Aufstieg des Hauses Sachsen-Lauenburg in Böhmen, in: Michael Wenger - Annemarie Röder (edd.), Barockes Erbe. Markgräfin Sibylla Augusta von Baden-Baden und ihre böhmische Heimat, Stuttgart 2010, p. 4-27; IDEM, Bohemia, Silesia and the Empire. Negotiating Princely Dignity on the Eastern Periphery, in: R. J. W. Evans - Peter H. Wilson (edd.), The Holy Roman Empire, 1495-1806, Leiden-Boston 2012, p. 143-165.

24 On careers at court, Henry Frederick Schwarz, The Imperial Privy Council in the Seventeenth century. With a supplement: the Social structure of the Imperial Privy Council (1600-1674), Cambridge 1943, p. 319-320; Václav BŮŽEK (ed.), Život na dvorech barokni šlechty (1600-1750), České Budějovice 1996 (= Opera historica 5); Rostislav SMíšEK, „Dvorskä“ kariéra očima knižete Ferdinanda ze Schwarzenberku, Jihočeský sborník historický 73, 2004, p. 94-120; IDEM, Služba a pamét. Dvorská kariéra barokních Ditrichštejnů jako nadgenerační životní ideal, in: Václav Bůžek - Pavel Král (edd.), Pamět' urozenosti, Praha 2007, p. 157-170.

25 On the representative function of noble residences, Petr MAŤA, Soumrak venkovských rezidencí. „Urbanizace" české aristokracie mezi stavovstuím a absolutismem, in: Václav Bůžek - Pavel Král (edd.), Aristokratické rezidence a dvory v raném novověku, České Budějovice 1999 (= Opera historica 7), p. 139-162; Jiří KubEš, Reprezentační funkce sídel vyšši šlechty z českých zemí (1500-1740), České Budějovice 2005 ( $\mathrm{PhD}$ thesis). 
instrumental to his promotion at the court, where he continuously needed to temper the doubtful perception of his loyalty to the crown, despite the formal appreciation for his trustworthy service in its defense.

In this light, the support offered to the Italian order of the Servi di Maria in Vienna had a specific relevance as for the efficacy in signifying Piccolomini's commitment to the Catholic church and in associating his patronage to the imperial one, therefore contributing to reinforce his public persona. A symbolic representation through the patronage of a religious order struggling to settle in Vienna, would signify his presence in the center of the Habsburg's power even when he was not there and much more effectively than any of his trouble-making representative could have done. The weakness of Piccolomini's network for the purposes of representation is extremely well mirrored in the sources, to the point that, while posted on duty on the several war fronts, Piccolomini had to repeatedly face the improper behavior of more than one of his agents causing him occasions of embarrassment that he remotely had to make up for calling on his fellow soldiers and few associates at the court. ${ }^{26}$ Jointly with economic issues and with the distance, between 1630 s and 1640s issues of representation were certainly determining the choice of the Servite church in Vienna as a far more convenient investment than the peripheral Náchod.

The protection granted to a religious order aligned Piccolomini's action with the most ancient European patronage tradition and was not only the expression of a sincerely religious feeling, but also constituted a social investment that would have a return in terms of reputation and prestige. ${ }^{27}$ By his culture and family tradition Piccolomini was active, throughout his life, in the protection of several religious orders, in which his family could count saints or blessed or within which, in the first half of the century, several members of the lineage had prominent positions. Beneficiary of Piccolomini's generosity had been, amongst others, the Dominicans in Cologne and the Friars of the Penitence of Saint Ciriacus in Prague. He was also strongly connected with the Jesuit order, of which a member of the family, another Francesco Piccolomini (1582-1651), was the Superior General between 1649 and 1651. Furthermore, in the footsteps of his papal ancestors, the fight against the heresy and the Turkish threat had been one of the defining traits of Piccolomini's public persona since his initial activity, so that he would be seen not only as the descendant of the last pope to call a crusade, Pius II, but a champion of the catholic faith himself. In 1650s the Jesuits were called by Picco-

26 Walter Leslie, Rudolf Colloredo and Maximilian Trauttmannsdorf (1584-1650) acted several times in this sense.

27 On self-representation through religious architecture in the territories of the empire see Jiří KROUPA, Art, Patronage and Society in Moravia 1620-1650, in: Klaus Bussmann - Heinz Schilling (edd.), 1648 - War and Peace, Münster 1998, p. 253-261. 
lomini in Náchod, in the framework of the recatholicization of an area where, as the lord of the estate and to comply with imperial orders, Piccolomini would be in charge to take action for the conversion of a non-Catholic majority. ${ }^{28}$

But the attention given by Piccolomini to the Servites far exceeds the assistance offered to any other religious institution. This commitment relates obviously to the origin of the order - funded in Florence in the 1200 s - and to the devotion that several members of the Medici family professed to the Santissima Annunziata, the Servites' mother-church in Florence housing a much-venerated image of the Virgin Mary. Likewise, it also certainly connects with the involvement of the Habsburgs in the promotion of the order, particularly in the person of Anna Caterina Gonzaga (15661621), archduchess of Tyrol, founder of the first Servite convent in Innsbruck and, in her widowhood, a Servite nun herself.
In 1634 Ottavio Piccolomini asked the Emperor for the fulfillment of a credit that he had with the court for 5.000 thalers, the price of a set of cuirasses paid by him to the killed rebel Trčka. Knowing that the restitution of the money would take time, because of the procedure for the description of the Bohemian rebels' properties, Piccolomini wrote to prince Hans Ulrich von Eggenberg (1568-1634), President of the Imperial Privy Council, pleading with him for the money to be given to the Vicar General of the Servi di Maria, Gioseffe Maria Suares, for the commencement of a church and convent of his Religion of the Servites, dedicated to the Santissima Annunziata. ${ }^{29}$ (Figure 3)

He then wrote a plea directly to the Emperor, asking him to give order for the money to paid to the General Vicar "to provide, as soon as possible, the necessary things for the construction of the church and convent that I desire (...) in honor of the Virgin Mary Announced. "30 The support

28 Samuele Laberhittel S. J. from Náchod to Piccolomini in Nuremberg, 4 June 1650, 1357, SOAZ, RAP; Piccolomini to Giovan Battista Formarini, 29 June 1650, 1359, ibidem; Laberhittel to Piccolomini, 26 December 1650, 1358, ibidem; Laberhittel to Piccolomini, 1 August 1651, 1365, ibidem. On the role of confessional identity in the shaping of the modern state, Wolfgang ReinHard, Reformation, Counter-reformation and the early modern state: a reassessment, Catholic Historical Review 75, 1989, p. 385-403; Heinz Schilling, L'Europa delle chiese e delle confessioni, in: Maria Antonietta Visceglia (ed.), Le radici storiche dell'Europa. L' età moderna, Roma 2007. On conversions in the empire in the Seventeenth century, Irene Fosi, Procurar a tutt'huomo la conversione degli heretici. Roma e le conversioni nell'Impero nella prima metà del Seicento, Quellen und Forschungen aus italienisch Archiven und Bibliotheken 88, 2008, 335-368; Mark Hengerer, The Courts and Princes Role in Reformation and Counterreformation in the Habsburg Territories 1500-1700, in: Howard Louthan - Graeme Murdock (edd.), A Companion to the Reformation in Central Europe, Boston 2015 (= Brill's Companions to the Christian Tradition 61), p. 338-358.

29 Copy of a letter of Piccolomini from the battlefield to the Prince of Eggenberg, 12 and 13, no date, ibidem: „Desidero che sieno impiegati in cominciamento d'una Chiesa e Convento della sua Religione de Servi dedicato alla Santissima Nunziata."

30 Copy of a letter of Piccolomini to the Emperor, 14, no date, ibidem: ,acciò che egli [Gioseffe Maria Suares] possa quanto prima provvedere le cose necessarie per la fabbrica della Chiesa e Convento che Io desidero si faccia in honore della Vergine Maria Annunziata." 


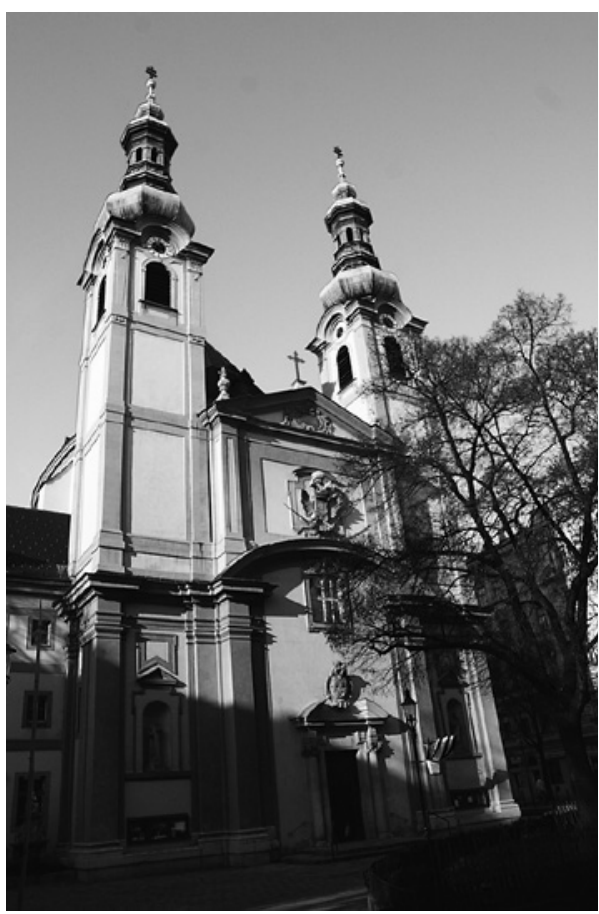

given to the Florentine religious order was also logistic, as more than once the Vicar General of the Servites was a guest of Piccolomini in Prague and Vienna. Naturally enough, Suares and other members of the order were part of the nobleman's network of intermediaries, acting in his interest jointly with his agents, Paolo Orsini and Felice Brunacci, with his brother, Ascanio
Figure 3 - Servitenkirche, Vienna

(Photo by author)

Piccolomini, and with his nephew, Francesco Piccolomini. ${ }^{31}$ Suares in particular was given a representative status and could gather information for the acquisition of other properties adjoining to Náchod, that had entered Piccolomini's possession with the farms of Heřmanice, Rýzmburk and Mala Skalice and to which, between 1636 and 1641, other properties in Miskolezy, Sonov, and Třebešov were added. ${ }^{32}$

\section{A Castle to barter, a Castle to keep}

The correspondence reflects Piccolomini's uncertain situation in the 1630s and 1640s as to his position at the court and to the establishment of a house. Sources present a double-fold attitude of the Tuscan nobleman that, while trying to find a buyer for the estate, at the same time gathers information about the chance to extend it, when possible, with properties promised by the court to his nephew Francesco. ${ }^{33}$

The waning of the impression caused by Wallenstein's assassination had not reduced the hatred and loathing addressed to Piccolomini by the German party at the court. Nonetheless, the Emperor's continuous trust in Piccolomini resulted in the

31 Gioseffe Maria Suares from Vienna to Piccolomini, 12 May 1635, 88, SOAZ, RAP: „Per causa della buona corrispondenza che passa fra Vostra Eccellenza Illustrissima et il Signor Principe di Pamberga [Franz von Hatzfeld, 1633-1642] (...) gl'ho per tanto offerto qui la sua Casa, e spesso lo riverisco, stando qui all'incontro. Da un amico mi vien fatto instanza come qui sarebbero 300 para di pistole di Mastorich di tutta bontà, se fussero buone per la sua Armata, si potrebbero havere per quanto mi ha accennato per 13 tallari 1/2 il paro“; idem from Prague, 15 September 1635, 90, ibidem.

32 Suares from Prague, 15 September 1635, 90, ibidem.

33 Giovanni Pieroni from Novy Hradek to Piccolomini, 29 September 1635, 15112, ibidem. 
attribution to him of the command of the imperial troops in the Lower-Rhine. There the Imperials were caught in the delicate situation of buttressing Spain in the fight against France and the United Provinces, that were neutral to the Habsburg empire. Piccolomini fulfilled the expectations placed on him networking with the local nobility as well as moving between Brussels and Namur to keep in touch with the reagent of the Spanish Netherlands, Cardinal Infante Ferdinand (1609-1641), brother of king Philip IV. His stance in Brussels was then confirmed as commander of the imperial troops in the Low Countries after his old fellow soldier, Ferdinand of Habsburg (1608-1657), succeeded his father in 1637 as Emperor Ferdinand III.

On the one hand, Piccolomini continued receiving information from his agents about possible buyers for Náchod: count Francesco Magni [count Strasnitz] will give 100000 thalers cash - Paolo Orsini wrote - countess Firstemberg married to count Harrach [Thekla Lavinia Maria widow Fürstenberg, wife of Otto Frederick von Harrach] will pay now 40000 thalers in spices, 20000 florins in jewelry, and the rest in four years; Giovan Battista Chiesa will pay 100000 thalers, half in jewelry, the rest in five years, the Vertemanni also 100000 thalers in six years paying the interests. ${ }^{34}$ On the other hand, Piccolomini obtained from the Emperor the permission to establish a fidecommisso on his properties and to write his testament in Latin, given that he did not speak the languages of the country, Czech and German. A schoolmaster was working steadily in Náchod between 1637 and 1638 and translating. pleas from Czech to Latin. At least in this first period, Náchod represented for Piccolomini a source of income because of the presence of copper mines, of the production of beer and of the privileges of hunting and fishing related to the administration of the estate and regulated by a series of agreements with the burgomaster of the town that lasted throughout the 1650s. ${ }^{35}$ As soon as Piccolomini became lord of Náchod, the townsfolk tried to secure its privileges, mainly in regard to brewing, appealing to the estate's administrator Orsini. Apparently, the privileges were not confirmed and, moreover, Piccolomini temporarily removed the revenues from customs duties levied at the city gates. ${ }^{36}$ The burghers were successful,

34 Orsini from Vienna to Piccolomini, 12 October 1635, 173, SOAZ, RAP: „Come Vostra Eccellenza mi disse, ho ritrovato da vendere Nacot e ne ritrovo 100 mila talleri nella seguente forma: Il conte Francesco Magno darà 100mila talleri alla mano contanti la Contessa di Firstembergo maritatasi col Conte d'Arac pagarà hora 40mila talleri (..) in spezie 20mila fiorini in gioie, il resto in quattro anni, Giovanni Battista Chiesa 100mila talleri, mezzi in gioie il resto 5 anni, li Vertemanni pure 100mila talleri in 6 anni pagando l'interessi (...).“"

35 On copper: Stefano Alberti to Polidoro Bracciolini, 9 May 1639, 1064, ibidem; Giacinto Comit to Bracciolini, 1 November 1649, 1065, ibidem; Filippo Talducci to count Testa Piccolomini, 13 December 1654, 1066, ibidem; on brewery: 1052-1058, ibidem; on spirits: 1059-1063, ibidem; on fishing in the castle pond: 1074-1082, ibidem; on hunting: 1089-1107, ibidem.

36 Lydia BašTecká - Ivana Ebelová (edd.), Náchod. Historie, kultura, lidé, Praha 2004, p. 96. 
though, in asking him to endorse their request to Ferdinand III for the permission to hold a third yearly fair, in addition to Saint Vitus' and Saint Martin's ones. In 1644 the right was granted for a fair to be held on Fat Thursday and for a weekly market of grain and cattle on Thursday. Despite the troubled times due to the war situations and the general decline of marketing and trades, in fact, fairs were still means of improvement for a city's income. Piccolomini was certainly interested in fostering the growth of the economy in the town given that, upon his order, his agents in Náchod would also take care of the selling of the grains as well as of the harvesting and seeding of the new crop. ${ }^{37}$ The revenues from the harvests were then to be used to pay his debts and interests on arrears. ${ }^{38}$ At the beginning of the same decade the castle was also equipped with furniture, silverware, paintings, tapestries, likely in view of a marriage project, that takes shape in this period in the Flanders, with Dorothée Caroline, daughter of one of Piccolomini's fellow soldiers, Albert François de Ligne, prince Barbançon and count Aremberg (1600-1674). ${ }^{39}$ It appears from the sources that Piccolomini was then considering several parties, but that, even in the absence of a formal proposal, the Barbançons took the arrangement as done and the rumor arrived as far as to Florence. ${ }^{40}$ Whichever the exact terms of the question, the project came to an abrupt end because of the death of the young princess, likely for smallpox, in May $1642 .{ }^{41}$

37 Orsini from Vienna to Piccolomini, 15 September 1635, 170, SOAZ, RAP. For a study on the dynamics of aristocratic landownership in the empire, Thomas Winkelbauer, Gundaker von Liechtenstein als Grundherr in Niederösterreich und Mähren. Normative Quellen zur Verwaltung und Bewirtschaftung eines Herrschaftskomplexes und zur Reglementierung des Lebens der Unterthanen durch einen adeligen Grundherrn sowie zur Organisation des Hofstaats und der Kanzlei eines „Neufürsten“ in der ersten Hälfte des 17. Jahrhunderts, Wien-Köln-Weimar 2008 (= Fontes rerum Austriacarum, 3. Abteilung, Fontes Iuris 19).

38 Piccolomini from Vienna to Bracciolini in Náchod, 22 April 1640, 15240, ibidem.

39 Albert Gaston Spinola count Bruay from Brussels to Piccolomini, 28 March 1637, 19119, ibidem: „Madame Votre femme ne faict que parler de Vous tous les jours devient plus belle." The silence of the sources on the celebration of a marriage reflects the difficult situation of the bride-to-be's father, imprisoned between 1634 and 1642 in Antwerp upon the unproven accusation of conspiracy against the Spanish crown. After he was discharged of any accusation, Piccolomini was appointed with the restitution to the prince of the honor of the Golden Fleece, of which he had been deprived during the imprisonment, Elster 1911,p. 84.

40 Francesco Useppi from Brussels to Piccolomini, 24 February 1641, 37, Archivio di Stato di Siena [State Archive in Siena] (hereafter ASS), Carte Benedetti Chigi Useppi [Benedetti Chigi Useppi Papers] (hereafter BCU); idem, 6 April 1641 and 21 April 1641, ibidem; Atanasio Ridolfi from Regensburg to Andrea Cioli in Florence, 23 April 1641, 4392, ASF, MDP, 4392; Evandro Piccolomini from Brussels to Piccolomini, 4 April 1639, 6940, SOAZ, RAP.

41 Luca Porcellotti from Brussels to Piccolomini, 10 May 1642, 31360, ibidem. Piccolomini remained on terms of courtesy with the whole family throughout his lifetime. On the matrimonial strategy of Imperial nobility, Rostislav SмíšEK, Šlechtic a sňatek ve drubé polovině 17. století. Sňatkové strategie Jana Adolfa a Ferdinanda ze Schwarzenberku, Folia historica bohemica 24, 2009, p. 167-198; IDEM, 
A month earlier Piccolomini had written to his commander in chief, archduke Leopold Wilhelm (1614-1662), asking him to intercede with his brother the Emperor for him to obtain a license from the imperial service, as he believed that his 26year long loyal service to the Empire was not being properly acknowledged. ${ }^{42}$ After Wallenstein's death, he had distinguished himself in 1634 in the battle of Nordlingen and, more importantly, he had brought the Imperials to the victory against France at Thionville in 1639 , a triumph that had gained him the gratitude of the king of Spain, the restitution of the Duchy of Amalfi and the access to the Imperial Privy Council. Following the disastrous defeat in Breitenfeld in 1642, where archduke Leopold Wilhelm, against his advice, had lead the imperial troops against the Swedish ones, Piccolomini was though taking leave and accepting Philip IV's invitation to serve in Spain.

Thinking that he would have settled down elsewhere, never to return to the imperial dominion, Piccolomini's perspective changed, once again, and he started negotiating the exchange of Náchod with properties that Prince Philip Wilhelm of Pfalzgraf Neuburg (1615-1690) had in the Kingdom of Naples. The negotiation with Neuburg was likely related to the recent recovery of the Duchy of Amalfi, whose possession the Piccolominis had lost in 1583 and that had been nominally returned to them in 1639 by the king of Spain. The process of enfeoffment of Amalfi to Piccolomini was complicated by the opposition of the local nobility. To obtain the title and jurisdiction on the duchy, Piccolomini would have had to pay 116660 ducats to several privates that had bought parts of the duchy from Spain..$^{43}$ The transaction with Neuburg was therefore oriented to strengthen the presence of the Tuscan family in that area, to fight the opposition of the local Amalfi nobility and to maintain a possibility for the establishment of a permanent mansion there under the patronage of Philip IV. The negotiation went far enough for a contract to be sent to baron Polidoro Bracciolini, administrator of Náchod and Piccolomini's agent in Vienna, though no trace of an effective swap of goods is documented in the 1640s.

In July 1643, while Piccolomini was on his way to Spain, via Venice and Florence, Bracciolini, had contacts with Neuburg through the prince's majordomo, his sonin-law's father. ${ }^{44}$ The prince was inclined to seal the agreement and offered com-

Die Heiratsstrategien der Fürsten zu Schwarzenberg 1600 bis 1750, in: Ronald G. Asch - Václav Bůžek - Volker Trugenberger (edd.), Adel in Südwestdeutschland und Böhmen 1450-1850, Stuttgart 2013 (= Veröffentlichungen der Kommission für geschichtliche Landeskunde in Baden-Württemberg 191, Reihe B), p. 127-154.

42 Piccolomini from Zeitz to Leopold Wilhelm, 17 April 1642, 22592, SOAZ, RAP.

43 Pier Luigi Rovito, Patriziato e governo municipale nella regione amalfitana tra i secoli XVII e XVIII, in: Franca Assante (ed.), La Costa di Amalfi nel secolo XVIII, Amalfi 1988, p. 197-217.

44 Giovan Domenico de'Servi's son, Wolfgang Wilhelm, had married Bracciolini's daughter Maria Maddalena. Filippo Baldinucci, Gostantino de' Servi, in: Notizie de' professori del disegno [1681-1728], (Firenze: Per Giovanni Batista Stecchi e Anton Guseppe Pagani, 1771). 
plete information on his possessions in Italy. Requested for the value of Náchod, Bracciolini declared the estimate in 300000 florins and reported that in time of peace, Piccolomini thought to be able to earn from it an annual revenue of over 25000 florins. ${ }^{45}$ Piccolomini, though, was still willing to consider other options, such as the renting out of the estate. Bracciolini then advised him to rent at a low price, so that the tenant would have had means to maintain the structures of the estate, for them not to ruin, and would not need to wait for revenues from the estate to pay for the price of it. ${ }^{46}$ Furthermore, while the sale was being adjusted, Náchod continued to be the main source of income for Piccolomini to support himself in his journey to Spain and in the long awaiting for an available galley to bring him there. The revenues, though, were not corresponding to the 9000 florins he had requested from his administrators. Because of the recurring incursions of the enemy - Bracciolini wrote - Náchod's peasants were spending more time hiding in the woods than in their houses, and the lack of traffic had affected the trades of beer, grains and groceries. Given the situation, while waiting for the secretary of prince Neuburg to send the papers concerning Naples, Bracciolini warmly invited Piccolomini to consider the possibility to make his lineage great elsewhere. ${ }^{47} \mathrm{Neu}-$ burg seemed nevertheless determined to conclude the exchange and in September 1643 provided Piccolomini's agent with the contract accounting for the state of his properties in Naples, where Piccolomini had in the meantime already asked for information about from the locals. ${ }^{48}$ A year later though the negotiation had not progressed. Piccolomini had arrived in Spain in October 1643 and was leaving for Flanders by March 1644 as appointed Governor General of the army in the Spanish Netherlands.

His seesawing attitude towards the sale of Náchod might have been depending not only on the uncertainty of his position at the court, but also by the death of most of the new generation of the Piccolomini's lineage, a difficulty that would certainly condition the settlement of the Piccolomini house anywhere out of Italy. After the death of two nephews - Silvio, dead at Nordlingen in 1634 and his brother Evandro, dead at Saint Omer in 1638 - while on his way to Spain in 1643 Piccolomini had lost his only male child, the natural son Ascanio, on the battlefield in Moravia.

Furthermore, the delicate equilibrium between revenues and expenses had to be managed longer. While in Spain, Piccolomini was informed that Náchod was not burdened with the passage of troops, but that more financial contributions were

45 Bracciolini from Augbsurg to Piccolomini, 24 July 1643, 23167, SOAZ, RAP.

46 Idem, 6 August 1643, 23170, ibidem.

47 Idem, 20 August 1643, 23172, ibidem.

48 Idem, 2 September 1643, 23174, ibidem. 
requested from the estate, as the Kingdom of Bohemia would have to support the empire with 320000 florins. At the court the rumor that Piccolomini was resigning from every office and that he was entrusting his nephew of the sale of Náchod was quickly spread. General Walter Leslie, one of Piccolomini's supporters at the court, commented with him that no buyer for the estate would have been found possessing appropriate means to pay for it, if not in the space of many years. On the other hand, when properly managed, Náchod would yield in his opinion a revenue of 28 to 30000 florins. ${ }^{49}$ Leslie's advice was well received by Piccolomini, that by the end of July had decided, once again, not to sell. ${ }^{50}$ Neuburg kept manifesting his interest in Náchod, though the action of Piccolomini's agents seems to indicate the final decision not to sell, possibly related to Piccolomini's new matrimonial plans. ${ }^{51}$ Formarini insisted in fact for the registra- tion in the Bohemian Chancellery of the privilege bestowed on Piccolomini and his descendants to include Náchod amongst the testable assets, something that was eventually accomplished only in March $1646 . .^{52}$

In the meantime, in June 1644 Piccolomini had already arrived in Flanders with the title of Governor General of the Army in the Spanish Netherlands where he would operate jointly with Francisco de Moura y Corterreal, marquis de Castelrodrigo (1610-1675) that would have held the political command. Náchod, then, became if possible even more peripheral. ${ }^{53}$ Contrasting rumors reported of Francesco de'Melo's reluctance to leave the post of Governor General in favor of Piccolomini and Castelrodrigo. In this context, while trying to find an appropriate accommodation for himself and his nephews in Flanders, Piccolomini had to face the umpteenth reassignment of his Viennese

49 Walter Leslie from Vienna to Piccolomini, 4 June 1644, 23771, SOAZ, RAP.

50 Leslie from Vienna to Piccolomini, 30 July 1644, 23777, ibidem.

51 Piccolomini to Orsini, 22 June 1644, 31956, ibidem: (..) intendo che la figliuola già sia promessa a (..); Formarini from Lintz to Piccolomini, 30 December 1644, 23692, ibidem: (..) mi disse che Vostra Eccellenza è grandemente innamorata d'una principessa di Zimai vedova, et che sia per maritarsi seco (..).

52 Piccolomini's property of Náchod had been registered in the Landtafel, the Bohemian land registry for real estate. Formarini from the Imperial court in Eberstorf to Piccolomini, 5 October 1644, 23679, ibidem; Orsini from Náchod to Piccolomini, 10 July 1635, 168, ibidem. Even for the registration of Náchod Piccolomini's nephew, Francesco, proved inadequate and inconclusive: Formarini from Lintz to Piccolomini, 30 March 1646, 24988, ibidem: „Se non si leva il Privilegio di testare Náchod, concesso 5 anni fa da Sua Maestà Cesarea, la cancelleria Boema dice che si cancellerà sendosi un decreto di Sua Maestà che se in termini di tre anni non si levano siano invallidi, diceva che lo avrebbe fatto il conte Francesco che non l'ha fatto."; idem, 15 May 1646, 24998, ibidem.

53 On the functionality of a dwelling in the vicinity of the court, Andrea PeČAr, Schloßbau und Repräsentation. Zur Funktionalität der Adelspalais in der Umgebung des Kaiserbofes in Wien (16801740), in: Ulrich Overmann - Johannes Süßmann - Christine Tauber (edd.), Die Kunst der Mächtigen und die Macht der Kunst. Untersuchungen zu Mäzenatentum und Kulturpatronage, Berlin 2007, p. 179-199. 
quarters. ${ }^{54}$ Several episodes had already shown Piccolomini how fragile his position could become at the court whenever he was not there, and had made him more aware of how rapidly his fortunes could overturn when, in June 1643, while he was heading to Leghorn to embark for Spain, his Viennese quarters were assigned to the aulic counselor Ettinghen, since Piccolomini was not using them. ${ }^{55}$ On that occasion, ten different pretenders had been aiming to that accommodation. The availability of lodgings close to the court was limited and the competition was tough to have a good assignation from the Quarter Master. ${ }^{56}$ The lack of promptitude of Piccolomini's agents - misusing the quarters, delaying the payments to the owner, hosting guests without notifying Piccolomini nor the court - had on several occasions given the court the pretext for the withdrawal, the substitution, or the rent to someone else, forcing Piccolomini to call on his supporters at the court to avoid the dislodging of his properties. ${ }^{57}$ The same happened again in December 1645. That the justification for a reassignment of Piccolomini's quarters to the aulic counselor Justus Gebhard was found in the hospitality given by Piccolomini's nephew, Francesco, to Atanasio Ridolfi (1641-1646), Tuscan resident in Vienna, speaks loudly not only for an actual difficulty in the remote managing of Piccolomini's interests, but also for the adversity of a part of the imperial court towards him. ${ }^{58}$ In June 1646 the matter had not yet been solved and Piccolomini's quarters were still disputed. In the meantime, absorbed by the effort to secure his position in Flanders, in September 1644 Piccolomini had elected his brother Ascanio as his representative for the taking of possession of the duchy of Amalfi, whose management appears in the sources slightly less troublesome than Náchod's. ${ }^{59}$ Ascanio then undertook new negotiations with the prince of Neuburg to barter Náchod with the city of Castellammare di Stabia, near Amalfi. ${ }^{60}$

54 Gabriel Campi from Brussels to Piccolomini, 12 October 1644, 31756, ibidem,

55 Leslie from Vienna to Piccolomini, 13 June 1643, 23295, ibidem.

56 On the hectic quartering procedure see John Philip Spielman, The court quartering system, chap. 4 in The city and the Crown: Vienna and the Imperial Court, 1600-1740, West Lafayette 1993, p. 75-100.

57 Formarini from Vienna, 10 August 1644, 23670, SOAZ, RAP. The owner of the house intended to sell to Franz Ulrich von Kolowrat that, as State Counselor, would always be in court.

58 Leslie from Lintz to Piccolomini, 5 December 1645, 24364, SOAZ, RAP. On Ridolfi, Florenz Tourtual, Dispacci Ridolfi. Des Florentiner Residenten Atanasio Ridolfi: Depeschen von Regensburger Reichstage 1641, Regensburg 1871; Francesco Martelli - Cristina Galaso, Istruzioni agli ambasciatori e inviati medicei in Spagna e nell' „Italia spagnola“ (1536-1648) II. 1587-1648, Roma 2007.

59 Ludovico Ridolfi from Florence to Piccolomini, 4 March 1645, 52511, ibidem. Several years later Piccolomini still lamented the loss of money in the managing of the property, while at his death none of the debts with the privates had been settled and the duchy came back to be property of Spain. Ottavio Piccolomini from Brussels to Domenico di Mena, 24 March 1648, 27069, ibidem: non potrà toccarmi molto al vivo il restare senza [Amalfi], non havendone mai avuto altro che spese o fastidij.

60 Bracciolini from Gansheim to Piccolomini, 15 July 1645, 101, SOAZ, RAP. 
While the possibility to come to a prompt definite conclusion of the exchange seemed more and more unlikely, Piccolomini started investing in the refurbishment of Náchod, in accordance with the imperial orders for the fortification of the estates most exposed to enemy attacks. ${ }^{61}$ Captain Giovan Battista Formarini, succeeding Bracciolini as an administrator in Náchod, would keep contacts with engineers and architects: with a little expense, even without imperial contributions, the fortifications could have been carried out effectively enough to benefit the whole estate, so to save on the yearly expenses on wood necessary for the patching of the damages and heavily impacting on the woods around the castle. ${ }^{62}$ Besides imperial orders and wedding plans, the revenues from the estate provided still a strong motivation for an investment to keep Náchod productive. Incomes from grains and beer kept being reinvested by Piccolomini in the honoring of his debts with his long-term agents and suppliers, such as the Italian Antwerp-based merchant Luigi Malo and the Verteman brothers in Prague. But in order to successfully do so, once again Piccolomini had to stem the pretensions of his nephew Francesco. As he demanded a monthly income from the estate, Piccolomini was forced to expressly state to the administrators that the proxy given to him only concerned the managing of the estate, whereas the revenues should be used to settle his accounts with Malo. ${ }^{63}$ As a matter of fact, the estate was Piccolomini's only substantial source of income throughout the fifth decade, to the point that his agents proposed to ask the Emperor for the contribution given by Náchod's subjects to the court to be attributed to Piccolomini instead, as a reimbursement for his expenses for the troops. ${ }^{64}$

Towards the end of 1647 Piccolomini's career was again at a crossroads, as he had been invited to go back and serve in Spain but was more inclined to return to the imperial court. ${ }^{65}$ After the death of Matthias Gallas in April 1647 Piccolomini expected to be called to fulfill the vacant post of Imperial Field Marshal, though Peter Melander count of Holzappel (1589-1648) was elected for the office and he obtained it only after the latter's death. In the same period he was appointed imperial negotiator at the execution diet in Nuremberg, called to set the demobilization of troops after the ratification of the Treaties of Westphalia. As the meeting lasted from May 1649 to November 1650 , Piccolomini had once again to remotely manage his interests related to

61 Formarini from Vienna to Piccolomini, 6 November 1648, 26732, ibidem.

62 Formarini from Náchod to Piccolomini, 29 June 1645, 24354, ibidem: Il Glotz vi è un valentissimo buomo di fortificazione col quale ho trattato che venghi sin qui per dare il suo giuditio nel ridur questo Castello in diffesa Reale; Formarini from Prague to Piccolomini, 26 August 1645, 24356, ibidem.

63 Piccolomini from the imperial camp near Gant to Pecori in Náchod, 6 July 1646, 239, ibidem.

64 Formarini from Lintz to Piccolomini, 13 July 1648, 26707, ibidem.

65 Leslie from Prague to Piccolomini, 9 November 1647, 25672, ibidem; Niccolò Paravicino from Prague to Piccolomini, 28 December 1647, 25749, ibidem. 
Náchod, Amalfi and the rented mansions in Prague and Vienna. Furthermore, the core of his funds had to be diverted now to the settling of a house in Nuremberg, appropriate to the representational needs of an imperial signatory and suitable for the reception of the other party's negotiator, Charles Gustav of Zweibrücken-Kleeburg (1622-1660), later Charles X king of Sweden.

For his effective role of mediation, Piccolomini had been nominated for the promotion to imperial prince and donated the ownership of a house in Vienna by the German princes participating to the conference. After the conclusion of the executive congress Piccolomini was not only the victorious commander, defender of the empire and of the catholic faith against the reform and the Turkish threat, but he could also promote his image as a peacemaker and diplomat. Aged enough to stop leading troops on the battlefield, his active military service had naturally decreased, bringing into focus his diplomatic activity. Piccolomini, then, definitely turned his attention to settling down and a new matrimonial project soon came to shape. In the light of such an eventuality the estate of Náchod acquired a different relevance. In addition to being Piccolomini's unique source of income, the castle was also becoming his only chance for the arrangement of a stable and lavish mansion of his own property, inescapable requirement for any noble wedding plan. In
June 1651 Piccolomini eventually married the sixteen-years-old Maria Benigna Franziska (1635-1701), daughter of Julius Heinrich von Sachsen Lauenburg (1586-1665), one of his fellow soldiers, and of Anna Magdalena von Lobkowitz (1609-1668).

The renovation of the castle, already started in the mid-1640s, peaked in the 1650s. As the owner, Piccolomini did not need to pay a rent for it, nor to purchase adjacent spaces to make it large enough to accommodate his family and suit, as it had been the unsettled case of the Viennese house. In the refurbushment of Náchod the former defensive function of the structure was taken into account, in line with the choices made in the same turn of years by other exponents of the court nobility for the renovation of their castles and fortresses into noble residences. Is this the case of the Lichtenstein castle in Valtice at the austro-moravian border, the Dietrichstein's in Mikulov, in Southern Moravia, the Collallto's at Brtnice, south-east of Prague. The architects called to work on these refurbishments - often Italians, such as Giovanni Maria Filippi (1565-c. 1631), Giovan Giacomo Tencalla (1591-1653), Giovan Battista Carlone (1603-1684), Giovanni Pieroni and Andrea Erna (not. 1617-1669) - would encircle the ancient nucleus of the castle with semicircular bastions and fortifications, providing it with a series of inner courtyards and often a chapel. ${ }^{66}$ The

66 For a study of the concept of Palazzo in Fortezza, as defined in Italian architectural treatises, and for its relation to the Italianate style, as a palace set amid real bastions or ravelins, see Thomas DACosta Kaufmann, Court, Cloister and City. The Art and Culture of Central Europe, 1450-1800, Chicago 1995, p. 223; Jiří Kroupa, Palác ve tvrzi. Umélecká úloha a zámecká architektura v raném novověku (Dvé úvahy k výzkumu svétské architektury ranébo novověku), Opuscula historiae artium. Studia minora Facultatis philosophicae Universitatis Brunensis 45, 2001, p. 13-37. 
general main reference for the adoption of this Italianate style in the noble fashioning of their houses arrived to this generation of patrons by the unforgotten example of Albrecht Wallenstein, that between 1620 and 1630 had been able to build and decorate the largest noble palace in Prague, employing there, as well as for his other Bohemian mansions in Jičín and Friedland, Italian artists such as Nicolò Sebregondi, Andrea Spezza, Santino Bossi, Baccio del Bianco and Giovanni Pieroni. ${ }^{67}$ Son of an architect of the Florentine court, architect himself, jurist, astronomer, friend of Kepler and Galilei, Giovanni Pieroni (1586-1654) had been sent to Vienna as a member of the Medicean retinue to the nuptials of Empress Eleonora Gonzaga. He had then become imperial military engineer, employed in the fortification of several burgs in the empire. ${ }^{68}$ Consequently - though most likely already acquainted with him because of the common Florentine origin - since 1634 Pieroni collaborated with Piccolomini within Wallenstein's entourage, of which both were members. Already in contact with Bracciolini in 1648 for the analysis of the new plan of the castle of Náchod, Pieroni was asked for a further plan for its fortification in $1652 .{ }^{69}$ Upon Pieroni's drawing Carlo Lurago (1615-1684), another Italian architect in Prague, carried out the construction of a bastion tower, three gates and the chapel. ${ }^{70}$ (Figure 4)

And particularly in the chapel the interest of Piccolomini in Náchod in the fifties is shown, well beyond the need for the fortification. The nobleman engaged in a correspondence to have the chapel decorated by the Florentine painter

67 Jiř́ Нrвек, Rezidenčni sît členư valdštejnskébo rodu v 17. a 18. století, Folia historica bohemica 28, 2013, p. 59-103. On Wallenstein’s patronage, Eliška Fučíková - Ladislav ČEPIČKA, Albrecht z Valdštejna a jeho doba, Praha 2007; Jiří HRBer, Mnichovo Hradistě jako valdštejnské rezidenční mèsto, in: Šlechtické rody a jejich sídla v Českém ráji, Semily 2009 (= Z Českého ráje a Podkrkonoší, Suplementum 13), p. 188-199; IDEM, Barokni Valdstejnové v Čechách, Praha 2013.

68 Jarmila Krčálová, Giovanni Pieroni - architekt ?, Uměni 36, 1988, p. 511-542; Petr Fidler, Kostel sv. Jakuba Vétš̌iho v Jičinè a architect Giovanni Battista Pieroni, in: Valdstejnská loggie a komponovaná barokni krajina v okoli Jičína, Semily 1997 (= Z Českého ráje a Podkrkonoší, Suplementum 3), p. 31-44; Guido CARrai, Nuovi documenti su Giovanni Pieroni e un'ipotesi per Palazzo Wallenstein, Umění 52, 2004, p. 537-542; IDEM, Giovanni Pieroni: uno scenografo forentino per l'incoronazione praghese di Eleonora Gonzaga (1627), in: Umberto Artioli - Cristina Grazioli (edd.), I Gonzaga e l'Impero. Itinerari dello spettacolo. Con una selezione di materiali dell'archivio informatico Herla (1560-1630), Firenze 2005, p. 161-174; Helena SeražIn, Poročila in risbe utrdb arbitekta Giovannija Pieronija, Ljubljana 2008; EADEM, Giovanni Pieroni's Reports about Fortresses on the Borders of Innerösterreich, in: Machtelt Israëls - Louis A. Waldman (edd.), Renaissance Studies in Honor of Joseph Connors I-II, Florence 2013, here I, p. 571-576.

69 Pieroni from Neustat to Piccolomini, 4 December 1634, 17194, SOAZ, RAP; Carlo Lurago to Piccolomini in Náchod, 19 May 1652, 1043, ibidem.

70 Lurago to Piccolomini, 19 May 1652, 1043, ibidem. For the contract see 228 and 1045, ibidem. Lurago's decorations in Náchod have been studied by Ulrike SEEger, Dekorationsentwürfe von Carlo Lurago für Schloss Náchod unter Fürst Ottavio Piccolomini, Zeitschrift für Kunstgeschichte 70, 2007, p. $89-112$. 


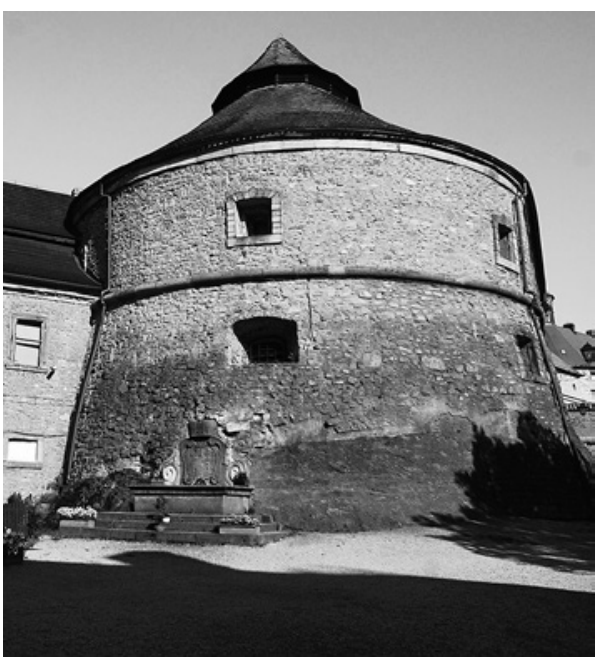

Mario Balassi (1604-1667). Met probably in Rome in 1630s within the Barberini circle, Balassi was a guest of Piccolomini in Vienna in 1652 and carried out several works for him before being invited to Náchod to paint the frescoes in the castle's chapel. ${ }^{71}$ Upon Balassi refusal Piccolomini turned to Lurago for contacts
Figure 4-Náchod castle, Eastern Bohemia, detail of the bastion with the Piccolomini crest (Photo by author)

and the architect co-opted Giovanni Vannetti, another less known Italian painter. ${ }^{72}$ Therefore, in Piccolomini's intention, Náchod would then become the permanent seat of his lineage in Bohemia, in the - unfulfilled - hope of an heir. Náchod would convey an identity that, though constructed in the imperial service across Europe, still found its cultural, political, social and religious roots in the descent from Pius II. That Piccolomini felt these roots as a precondition of his political and military action, and the essential basis for his self-representation, is most clearly signified in the long inscription on one the gates built in 1650s in Náchod: there Piccolomini's Etruscan origin and the descent from Caterina Piccolomini, sister of Pius II, are celebrated well before his military successes. ${ }^{73}$ (Figure 5)

71 For a reconstruction of the relationship with the painter Alessandra Becucci, Mario Balassi 1604-1667, Florence 2005 (Master's thesis), p. 148-179.

72 Lurago from Prague to Piccolomini, 18 April 1654, 1046, SOAZ, RAP; idem, 10 April 1655, 1049, ibidem; idem, 10 August 1656, 1050, ibidem. About Giovanni Vannetti - Oldřich J. BlAžíč́EK, Contributi Lombardi al barocco boemo, Arte lombarda 19, 1974, no. 40, p. 147-162; Winfried TöPler, Das Kloster Neuzelle und die weltlichen und geistlichen Mächte 1268-1817, Berlin 2003, p. 249.

73 For Piccolomini's patronage between 1640s and 1650s A. Becucci, L'arte della politica. Piccolomini's family painting gallery is the object of a forthcoming article, due in June 2017. To date, limited information can be found about it in Jaroslav Wagner - Ivan Muchka - Jarmila Netкоvá, Náchod, státní zámek, jeho obnova a prezentace, Památky a prýroda. Časopis státní památkové péče a ochrany prírody 4, 1979, p. 65-81, here p. 75, and Milan Žd’árský, Rodová galerie Piccolominiu na zámku v Náchodé, České památky, Casopis pro prátele památek a historie 10, 1999, p. 5-7. On noble imperial patronage, amongst others, Hellmut LoREnz, Ein Exemplum fürstlichen Mäzenatentums der Barockzeit - Bau und Austattung des Gartenpalastes Liechtenstein in Wien, Zeitschrift des Deutschen Vereins für Kunstwissenschaft 43,1989, p. 7-24; Petr Fidler, Spanische Säle - Architekturtypologie oder -semiotik?, in: Wolfgang Krömer (ed.), Spanien und Österreich in der Renaissance, Innsbruck 1989, p. 157-173; IDEM, Die Bautätigkeit der Familie Pálfy im 17. Jabrbundert und der Umbau des Schlosses Bibersburg-Červený Kámen, Ars 3, 1994, p. 213-236. 


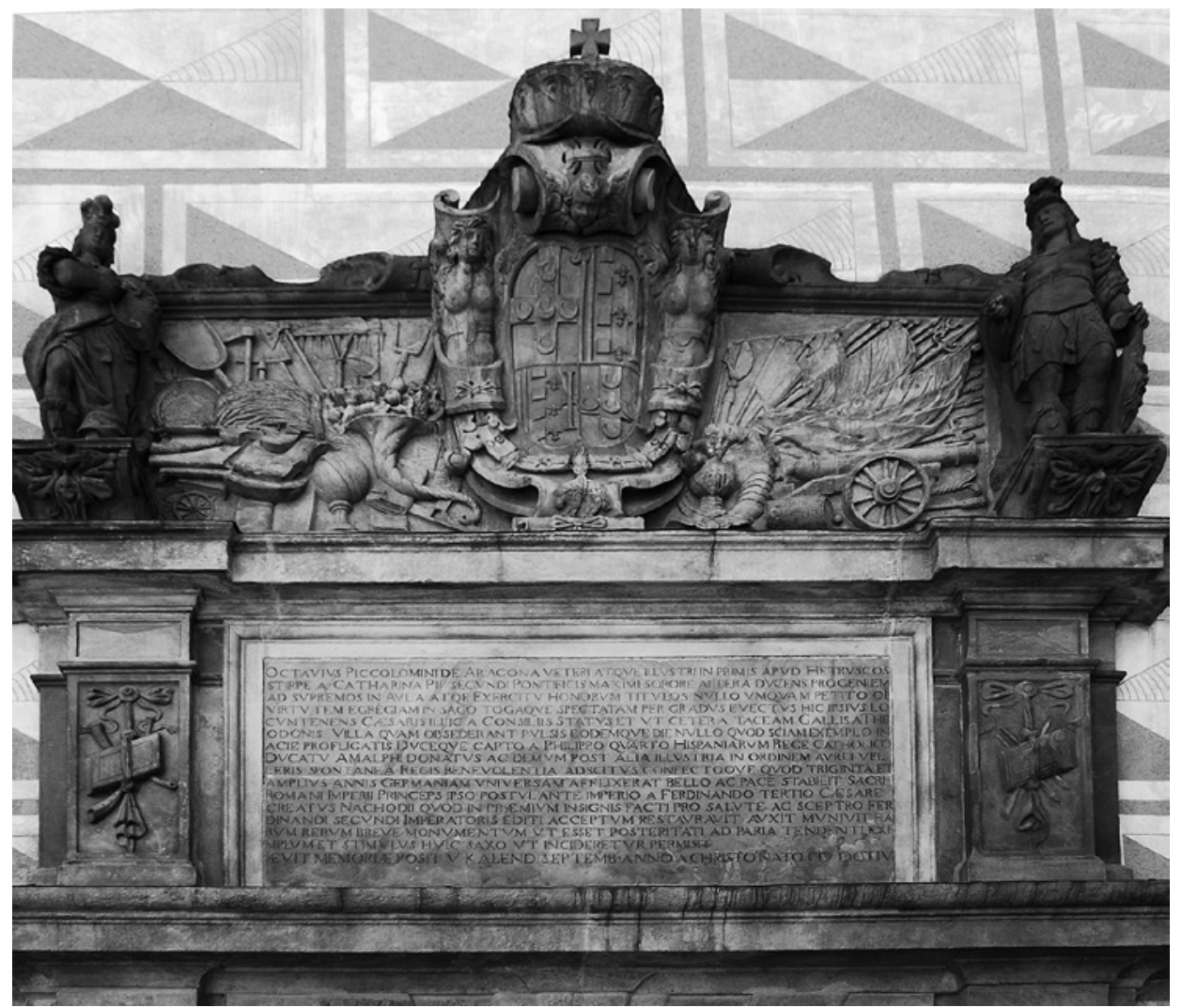

Figure 5 - Náchod castle, Eastern Bohemia, detail of the North gate (Photo by author)

\section{A church to be funded}

In the meantime, the building of the Servite church was far to be completed. ${ }^{74}$ The first petition by the abovementioned Gioseffe Maria Suares to Ferdinand II for the foundation of a church dated to 1626 and had been supported by a recommendation of the emperor's brother, archduke Leopold, founder of the Servite church of Maria Waldrast in Tyrol in 1621. A plea had also arrived from Leopold and Ferdinand's sister, Maria Magdalena

74 On the Servite order in the Habsburg empire: Christopher A. M. Mooney, The Servite Germanic Observance (1611-1668). Foundation, expansion and final Papal approval. The Theology and Practice of the Religious Life, Studi Storici dell'ordine dei Servi di Maria 16, 1966, p. 5-81; 19, 1969, p. 133243; Luke M. Foster, Theology and theologicians. The Servite Germanic observance, 1636-1783, Studi Storici dell'Ordine dei Servi di Maria 27,1977, p. 5-162; Veronika ČAPská, Představy společenství a strategie sebeprezentace. Řád servitư v habsburské monarchii (1613-1780), Praha 2011. 
grand duchess of Tuscany. For a few years resistances to the Servite's establishment in Vienna were motivated with the existence, as of 1627, of a Servite convent in Prague, though the main difficulty was the presence of several other religious orders in Vienna for which the Servites would have been competition. This, jointly with the unwise habit to bypass the bishop while appealing directly to the emperor or to the city council, weakened the Servites' position, resulting in the refusal to allow them to beg for their maintenance and in the rejection of their requests to be assigned the church of Maria am Gestade and then the church of Saint Peter. After a nine-years pause, Suares, in the meantime elected General Vicar, had pleaded again for the permission to build a house for the order in Vienna. The choice fell then on the Prater area, approved by the bishop in 1636, though with the prohibition to the Servites to beg and panhandle, as that would have damaged other orders already settled in town. Not even the Prater area turned out to be suitable, as the Emperor believed it would be too close to the Carmelites and too much exposed to floods and ice, because low. The Emperor suggested then the Rossau quarter of the town, but the Servite presence was newly opposed by the Bishopric and by the civic authority because of the high number of other religious orders in town, believed to be more than sufficient. After the death of the Emperor, the friars appealed to his successor, Ferdinand III, reminding him that his father had given his word for a foundation of their order and that they had committed to self-support themselves without begging. In 1638, after more resistances and several refusals from the bishop, the city council and the Imperial Privy Council, the emperor eventually gave his brother archduke Leopold Wilhelm order to take care of the promotion of the Servites. Negotiations were then undertaken with owners of properties in the Rossau for the purchase of some land where to build the convent and the church. Finally, in May 1639 a chapel was built on land donated by a widow, consecrated as „Bethlehem“ and dedicated to the Virgin Announced in the presence of the emperor Ferdinand III and his wife, their son Ferdinand, the archduke Leopold Wilhelm, the apostolic nuncio Malatesta Baglioni and several members of the nobility. The new General Vicar of the order Arcangelo Benivieni brought a copy of the painting with the Announciation of the Virgin Mary conserved in the mother church, Santissima Annunziata in Florence. ${ }^{75}$

As mentioned above, Piccolomini's involvement in the establishment of the Servites dated back to 1634 . One year later, in 1635, he donated the Servites his property in Miskolezy to pay for the construction of the convent, but the actual transfer of the money took long. The friars had to beg Piccolomini to give them at least a minimum sum to initiate the construction,

75 Karl Lechner, Kirche und Kloster der Serviten in der Rossau in Geschichte und Kunst, Wien 1970;

Claudia Ulrike Lavicka, Geschichte der P. P. Serviten in der Rossau in Wien bis zur Mitte des

19. Jahrhunderts, Wien 1971 ( $\mathrm{PhD}$ thesis). 
fearing that the authorization would have been withdrawn when appearing that they were not ready to settle. ${ }^{76}$ Resilient to any oppositions, the Servites managed to obtain a permission to beg in 1640 , provided they would not impact on other orders' activity. Piccolomini assisted them again in 1641, when his agent Polidoro Bracciolini suggested that the funds to complete the promised donation of 10.000 thalers, of which the friars only had had 4000 , could be retrieved form the sum donated by the Emperor to Piccolomini's nephew, Francesco, out of the confiscations in Bohemia. A Mr. Gersbero Wosckhi had to be forced in 1643 by Prague's city authorities to pay Francesco the sum of money, that Bracciolini then passed to the Servites. Before doing so, though, Bracciolini asked Piccolomini to give order for 3 to 4000 thalers to be paid yearly from Náchod's revenues to Francesco, for him not to be held as
Francesco's debtor. The whole process was closely monitored by the Servites. Father Cherubim Maria O'Dale (1600-1664) - a guest of Piccolomini while awaiting the final construction of the church - went to Prague in person and called on count Jaroslav Bořita $\mathrm{z}$ Martinic (1582-1649) and on other members of the imperial council to speed up the practice in the tribunal of the city. ${ }^{77}$ Sources are clear about the level of obstinacy and determination of the friars and on their more than active collaboration with their benefactors in view of the foundation of their church and convent: in order to test Piccolomini's intentions and possibilities, O'Dale contacted the nobleman's Jesuit confessor, father Jan Batista Van Holland. ${ }^{78}$ In 1643 an enlargement of the "Bethlehem" chapel was decided and, before leaving Vienna for Italy to embark for Spain, Piccolomini set for the transfer of more funds to the order. ${ }^{79}$ So, the proper-

76 Suares from Vienna to Piccolomini, January 1635, 85, SOAZ, RAP.

77 Bracciolini from Vienna to Useppi at the Imperial camp, 25 December 1641, ASS, CBU; idem, 9 January 1642, ibidem; idem, 21 January 1642, ibidem; Piccolomini from Zeitz to Cherubim Maria O'Dale in Vienna, 28 March 1642,1, Archiv des Wiener Servitenkloster [Archive of the Servite Church and Convent in Vienna] (hereafter AWS), Sect. II A Conv. Vien. II (hereafter II A II): , (...) la difficoltà che fa il Gesberoski non è che per metter lunghezze al pagamento. Io mando qui acchiusa una cession in forma solenne, con la quale spero che se gli leverà ogni occasione di renitenza (...)“; O’Dale from Vienna to Arcangelo Benivieni, 26 August 1642, 4, ibidem; Benivieni from Innsbruck to Piccolomini, 8 August 1643, 8, ibidem; Piccolomini from Florence to Benivieni in Innsbruck, 25 August 1643, 9, ibidem; For Cherubim O'Dale: Christopher A. M. Mooney, Donagh O'Daly, 1600-1664: A forgotten Irish Figure of the Counter-Reformation in Austria e Bohemia, Studia Hibernica 19, 1979, p. 7-25.

78 Jan Baptista van Hollant to O'Dale in Vienna, 13 August 1642, 3, AWS, II A II; van Hollant to O'Dale in Vienna, 18 March 1643, 6, ibidem.

79 Piccolomini from the imperial camp near Dresden to O'Dale, 11 March 1643, 5, AWS, II A II; O’Dale from Vienna to Benivieni in Innsbruck, 5 May 1643, 7, ibidem: „...) hieri doppo baver Sua Eccellenza fatto ben lunga oration nella nostra Capella et essendosi doppo meco confessato, s'e dichiarato di voler assistere con tutto l'affetto alla comminciata opera di questa fundatione et assegnarsi sopra delli 15 mila forini una summa di 10mila forini appresso l'Imperatore et alcuni altri mila altrove. Il cb'hoggi esplica chiamandomi alla Sua presentia col Baron Bracciolini al quale diede ordine di provedersi quanto 
ty of Choteč near Jičín, in Bohemia, was assigned to the Servites and they sold it to Rudolf von Tiefenbach (1582-1653) for 16000 thalers. $^{80}$

The posing of the first stone for the new church was though only celebrated by the bishop of Vienna on 11 November 1651, Saint Martin's day and Piccolomini's birthday, in the presence of the emperor, the empress, their sons, the apostolic nuncio Camillo Melzi, the ambassadors of Spain and Venice, but, apparently, in the resounding absence of Piccolomini's young spouse. A medal was placed next to the stone with an incision Memoria Fundatore / Octavio Piccolomini de Arragona /S. R. I. Principe $/$ Duce Amalphi. As a matter of fact, in the book of the Servites Priorate of Vienna Piccolomini appears as haud dubie primario Fundatori, first of a long list of excellent patrons of the church and convent, with an initial commitment for a donation of 22000 florins to be later augmented. ${ }^{81}$

By the time Piccolomini passed away the church had not been completed and, following the provisions of his will, his body was temporarily placed in the first structure built by the Servites. ${ }^{82}$ Only later he was buried anonymously, in the chapel of the Virgin Mary of the Seven Sorrows to the left in the new church. No source is explicit as to the artists involved in the first stages of the construction and it is therefore impossible to relate Ottavio's artistic patronage to any specific artist. Only towards the end of the century the names of Carlo Martino Carlone (16161667) and Carlo Canevale (1625-1690) are associated in the documents with the definitive design of the church. As for the Piccolomini patronage, only in 1671 one of Ottavio's nephews, count Enea Piccolomini Caprara (1601-1731), signed a contract for the decoration of the chapel where the uncle had been buried. ${ }^{83}$ Even then, though, no gravestone bearing his uncle's name was added and the memory of Piccolomini remained symbolized by the existence of the church itself, by the crest on the archway of his chapel and, on the façade, by the family crest and statue of the blessed Gioacchino Piccolomini. ${ }^{84}$

prima di 5000 fiorini per dar principio alla fabrica, e che poi ogni anno di più ci dia mille fiorini incerca dalla Signoria di Nachott. Promette poi nel rimanente voler successivamente adgiustare et assitere, massime dandoli Dio nostro Signore buoni successi in questa impresa di Spagna (...).“

K. Lechner, Kirche, p. 12, 13.

Liber Prioratus seu Informatio de Origine Venerabilis Conventuus Divae Virginis Annuntiatae Viennae in Rosavia Ordinis Servorum B. M. V. ab Anno 1639 usque ad 1689 adscripta Bibliotheca et Supellectili Ecclesiae et Conventus, AWS, C IV 4.

82 Last will and testament of Ottavio Piccolomini Pieri d'Aragona, Vienna, 6 July 1656, 44, 8, ASF, Guadagni.

83 K. Lechner, Kirche, p. 21

84 On the importance of burial sites in the representation of imperial nobility in the early modern time Mark Hengerer (ed.), Macht und Memoria. Begräbniskultur europäischer Oberschichten in der Frühen Neuzeit, Köln-Weimar-Wien, 2005; Andreas H. ZAjıc, Grabdenkmäler des späten Mittelalters und der Frühen Neuzeit als Quelle adeliger Erinnerung und Medium adeliger Repräsentation, Sborník prací 


\section{Conclusions}

More than along the lines of several other prominent members of the imperial court society, whose patronage would reflect the uprising of individuals that were already benefitting from the prestige recognized to their lineage, Ottavio Piccolomini followed in the footsteps of the homini novi, whose popularity at the court - regardless for their original social and economic situation - was exclusively depending on their personal success or failure, such as Rambaldo di Collalto and, more evidently, Albrecht von Wallenstein. His interest in the castle of Náchod and in the church of the Servites in Vienna can be interpreted in the light of both the spatial dimension of his action - in the mobility inherent to his activity as soldier and diplomat - and the ineludible relation between center and periphery in the socio-political dynamics of the Habsburg territories. For Piccolomini, constantly engaged in political and military missions, self-promotion was tied to the quality of his agents - family, associates and patrons - and of their action. In the struggle to establish his position at the court, his presence needed to be felt and remembered even during his frequent absences. Differently, his reputation, fame and possessions would suffer, regardless for his merits on the battlefield. The castle and estate of Náchod represented an economic investment whose importance was not matched by its potential in terms of representation. While Piccolomini was on his way to Spain, his son's wagon was attacked and robbed in the surroundings of the castle by the imperial troops stationing there. When the servants complained, and revealed the name of the owner of the wagon and of the land, the imperials continued their assault answering that Piccolomini was not in Germany anymore. ${ }^{85}$

Piccolomini's attraction to Vienna, center of the sovereign power and place of the first formulation of any political discourse, expresses both the desire to represent his own symbolic power - in the funding of the Servite church and convent - and to control his own personal image and the one of his lineage, in a time in which the economic capital could only become fully effective when associated with the cultural one. ${ }^{86}$ Apart for the sincere religious feeling that the patronage of the Servites

Filozofické fakulty Brněnské univerzity 51, 2002, řada historická 49, 2004, p. 155-206; IDEM, „Zu ewiger gedächtnis aufgericht", Grabdenkmäler als Quelle für Memoria und Repräsentation von Adel und Bürgertum im Spätmittelalter und in der Frühen Neuzeit. Das Beispiel Niederösterreichs, Wien-München 2004 (= Mitteilungen des Instituts für Österreichische Geschichtsforschung, Ergänzungsband 45).

85 Bracciolini from Vienna to Piccolomini, 16 May 1643, 23160, SOAZ, RAP.

86 K. J. MacHardy, The rise of Absolutism and Noble Rebellion in Early Modern Habsburg Austria, 1570 to 1620, Comparative Studies in Society and History 34, 1992, p. 407-438; EADEM, Social Mobility and noble rebellion in early modern Habsburg Austria, History and Society in Central Europe 2, 1994, p. 97-139; EADEM, Cultural capital, family strategies and noble identity in Early Modern Habsburg Austria 1579-1620, Past \& Present 163, 1999, p. 36-75; EADEM, War, Religion and Court Patronage in Habsburg Austria. The Social and Cultural Dimension of Political Interaction, 1521-1622, New York 2003. 
embodied for Piccolomini, the sponsoring of the church would have a more immediate return in terms of prestige. It would in fact represent the Italian nobleman not at the borders of the empire, but right in the capital of the realm. Furthermore, unlike the private and interested patronage involved in the care of the estate of Náchod, the patronage of the church would represent him as acting in the interest of a pious cause and, given the charisma of the order, of the whole civic community. This element, peculiar to the mission of the order, devoted to the assistance to those in need and to the conversion of the masses, contributed to delineate an image of Piccolomini as a strenuous defender of the Catholic faith - in his own ancestor's footsteps - and as a pious gentilhuomo, something that would positively impact on the reputation of pitiless assassin of his commander spread about him at the imperial court. The foundation of a church financed with the goods sequestrated to the Bohemian rebels appears, politically, as much more effective than the settlement in one of the castles of Wallenstein. Once dead, in fact, the Bohemian general was being more and more justified in several of his actions, to the point of being regarded more as a victim than as a traitor, for the ruin of his executors' reputation. Since Piccolomini in particular had made himself hateful to the German nation, the choice of the Florentine Servite order

Figure 6 - Servitenkirche, Vienna, detail of the façade, statue of Gioacchino Piccolomini, Piccolomini and Servites crests (Photo by author) would also allow him to connote positively his Italian origins, in a moment in which the loyalty of the Mediterranean imperial servants was qualified by contrast with the one of the Germans. Besides, in sponsoring the Servites Piccolomini would also celebrate his own dynasty in the person of the blessed Servite Gioacchino Piccolomini (1258-1306). The fact that Gioacchino's real belonging to the Piccolomini family was in the seventeenth century still sub iudice would not diminish his symbolic potential as a member of the Piccolomini pantheon of blessed and saints, as proven by the statue still on site on the façade of the Viennese church. (Figure 6)

Furthermore, Gioacchino was remembered in one of the chapels of the
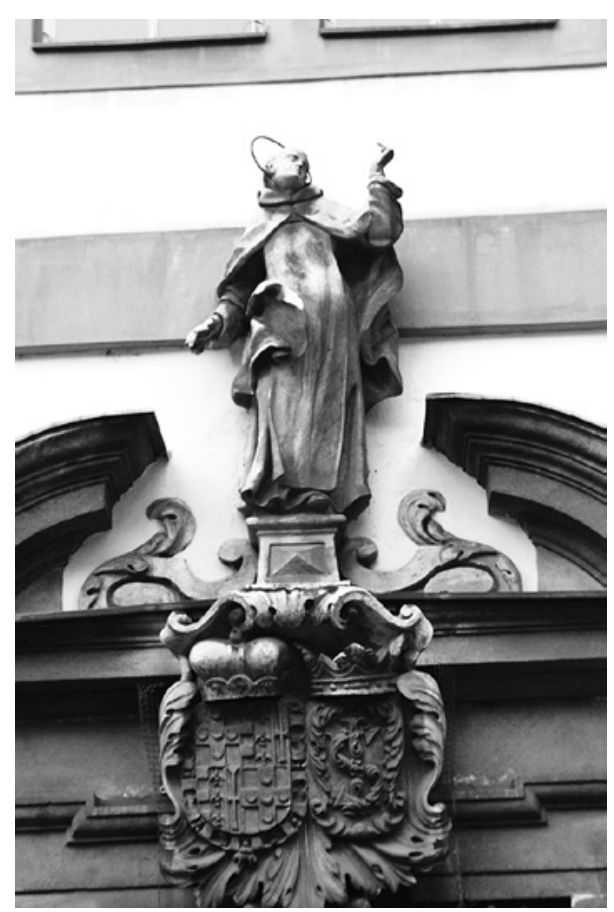
mother church in Florence. Indeed, the Florentine origin of the Servites would also allow Piccolomini to associate his patronage with the one of his first patrons, the Medici, particularly devoted to the Florentine sanctuary. In the Hasburgs territories the Medicean protection to the Servites was not only expressed in the recommendation of the dowager duchess Maria Magdalena to her brother the emperor, but was also conveyed in the action of Claudia de' Medici (1604-1648), sister of the Medici grand duke, and archduchess of Tyrol, with which Piccolomini maintained a regular correspondence throughout his life. The archdukes had facilitated the settlement of the Servites in Prague in 1626, the foundation of their church of Matrei am Brennen in Tyrol and had pleaded the emperor and pope Urban VIII for the concession of a permit to erect their church in Vienna. Claudia had then mediated the passage of the former Franciscan church of Maria Luggau in Carinthia to the Servites. As the principal founder of the Servite church and convent in Vienna, Ottavio Piccolomini would therefore promote his image as a patron next to both the Medici, his former patrons in his court of origin, and the Habsburgs, the patrons he had chosen to actively serve. The first promoter of the Servite order in the Habsburg territories at the beginning of the Seventeenth century had been Anna Caterina Gonzaga (1566-1621) arch- duchess of Austria, founder of the Servite convent in Innsbruck and, throughout her widowhood, a Servite nun herself as sister Anna Juliana - together with her daughter Maria. Cherubim O'Dale (1600-1664), one of the friars mostly in touch with Piccolomini from the 1630 s well into the 1650 s and acting as a member of the nobleman's network, had been adopted by Anna Caterina and had later become her confessor. ${ }^{87}$ Besides the authorizations of both Ferdinand II and Ferdinand III, then, in the building of the church several members of the court were involved and particularly the imperial counselor Elias Schiller, whose commitment in the foundation was second only to Piccolomini's one. For all these reason, the investment of funds and energies in the convent and church of the Servite was for Piccolomini until 1650 's more effective than any plan he might make on the castle.

The peripheral option - Náchod - besides necessitating of a higher economic investment and of a tight and continued control that Piccolomini was not able to exercise in the fourth and fifth decade, would only become effective in the 1650s. Then, the expression of the prestige of the Piccolomini family in Bohemia - once mostly military - took shape in the late attention devoted to the establishment of Ottavio's own lineage, in the fruitless pursuit for a descendant: in view of this project the former mili-

87 Piccolomini, Instruction to the majordomo, ca. 1653-1654, 14717, SOAZ, RAP; O’Dale from

Prague to Piccolomini, 14 August 1654, 13717, ibidem; O’Dale from Prague to Piccolomini, 13719, 27 May 1655, ibidem. 
tary fortress of Náchod was turned into a noble mansion.

In the end, though, to make the lineage great in Bohemia, self-representation through architecture, for how effective it might be, would not suffice. The depiction of Piccolomini's entombment in the letters of the Tuscan resident at the imperial court clearly signifies how the lack of an heir could hardly be compensated by other family members: "Yesterday at one hour in the night he was brought in a luggage wagon in a coffin, and with only two torches, out in the quarter of the Church begun by His Excellence for the Servite Fathers of the Santissima Nunziata in Florence, where he will remain until something else is made of him; the mentioned wagon was preceded by the Princess in a coach-and-six, but the servants were dressed in turquoise, and then the coach of the Counts Caprara followed, also without black; in seeing such a retinue I was moved, in seeing the cadaver of a man of that kind brought to the entombment as if infected by the plague." 88

88 Felice Marchetti from Vienna to the Florentine court, 12 August 1656, 4400, ASF, MDP: „Hiersera all'un hora di notte fu portato in un carro da bagaglio entro una cassa, e con due sole torcie fuori ne borghi della Chiesa principiata da Sua Eccellenza a' Padri Serviti della Santissima Nunziata di Firenze, ove starà in deposito fino a che se ne faccia altro; al suddetto carro precedeva la Signora Principessa in una carrozza a sei, ma i servitori erano vestiti di turchino, e seguitava poscia la carrozza con i Signori Conti Caprara pure senza bruno; Io che veddi simile accompagnamento m'intenerii nel vedere il cadavere d'un huomo di quella fatta condotto a guisa de gl'appestati alla sepoltura." 
Alessandra Becucci

\section{A Church and a Castle. Centre and periphery of the Empire in duke Ottavio Piccolomini's self-representation (Abstract)}

In 1634, while trying to sell his castle in Náchod, duke Ottavio Piccolomini (1599-1656) started diverting his resources towards the foundation of the church of the Servite order in Vienna. The Florentine origin of the order, the church's closeness to the center of the Habsburg power and the involvement of other notable patrons in the establishment of the Servites in Vienna are some of the elements that made the church a more suitable investment than the castle for Piccolomini's need of social and political representation. This contribution analyses the symbolic capital conveyed by both buildings at different stages in Piccolomini's career as instrumental to his fashioning within the highly-competitive Viennese court society.

KEY WORDS:

Self-representation; patronage; artistic patronage; nobility; Ottavio Piccolomini 